\title{
Wat was, werd en wordt belangrijk in het algemene subsidierecht?
}

\author{
Rianne Jacobs en Willemien den Ouden
}

\begin{abstract}
Aanbevolen citeerwijze bij dit artikel
Rianne Jacobs en Willemien den Ouden, 'Wat was, werd en wordt belangrijk in het algemene subsidierecht?', Netherlands Administrative Law Library, januari 2014, DOI: 10.5553/NALL/.000017
\end{abstract}

\section{Inleiding}

Titel 4.2 van de Awb regelt het algemene subsidierecht. Deze 'subsidietitel' die, als onderdeel van de derde tranche van de Awb, op 1 januari 1998 in werking trad, kende een roerige voorgeschiedenis. Er waren een paar flinke affaires, compleet met parlementaire enquêtes, ${ }^{\mathbf{1}}$ voor nodig om door te laten dringen bij politici dat het subsidiebeleid wel erg mager was genormeerd. Toen de Algemene Rekenkamer aan het einde van de jaren tachtig van de vorige eeuw constateerde dat het subsidiebeleid niet alleen bij EZ en VROM, de twee ministeries die bij de parlementaire enquêtes onder vuur hadden gelegen, maar bij alle ministeries tekortschoot, was dat de druppel. Het kabinet Lubbers-III (1989-1994) kondigde een pakket maatregelen aan gericht op verbetering van het beheer van subsidiegelden, vermindering van de fraudegevoeligheid en een verduidelijking van de juridische kaders. Dit "geïntegreerd subsidiebeleid" 2 moest ook leiden tot beheersing van de subsidie-uitgaven. Sluitstuk waarop de regering aanstuurde, vormde een algemene wettelijke regeling voor subsidies. Op dat punt sloot het geïntegreerd subsidiebeleid mooi aan op het lopende proces van totstandkoming van de Algemene wet bestuursrecht.

Maar niet iedereen was even enthousiast over dit voornemen. In artikel 107, tweede lid, van de Grondwet, de bepaling die aanleiding gaf tot de ontwikkeling van de Awb, staat niet voor niets dat de wet algemene regels van bestuursrecht vaststelt. Volgens sommigen was het subsidierecht vooral sectoraal van aard. 3 Het was in ieder geval een stuk minder algemeen dan de onderwerpen die tot dat moment in de Awb waren gecodificeerd, aldus de Raad van State. ${ }^{4}$ De regering zette toch door en daarom kent de Awb nu een subsidietitel van maar liefst zestig artikelen. Bij het vastleggen van al die algemene regels van subsidierecht had de wetgever minder houvast aan de bestaande rechtspraktijk, dan bij andere onderdelen van de Awb het geval was geweest. Er kon niet worden volstaan met codificatie van min of meer uitgekristalliseerde leerstukken. De praktijk van het subsidierecht (wetgeving, literatuur en jurisprudentie), liet op dat moment namelijk een zodanige diversiteit zien dat echte keuzes door de wetgever moesten worden gemaakt. 
Dat maakt juist dit deel van de derde tranche van de Awb interessant om, vijftien jaar na inwerkingtreding daarvan, tegen het licht te houden. Wat hebben de (op sommige punten principiële) keuzes van de wetgever ons inmiddels gebracht en in hoeverre zijn de doelstellingen die de wetgever had bij het ontwerpen van de subsidietitel bereikt?

Een dergelijke, nogal algemeen geformuleerde vraag over een omvangrijke regeling, die bovendien gevolgd is door een enorme hoeveelheid uitvoeringsregelgeving, is lastig te beantwoorden binnen het aantal pagina's dat voor een artikel nog acceptabel is. Bovendien is er inmiddels veel geschreven over het Awb-subsidierecht en is de jurisprudentie bepaald overvloedig te noemen. 5 Dat materiaal is veel te omvangrijk om hier, zelfs maar op hoofdlijnen, te behandelen. Daarom hebben wij ervoor gekozen om niet alle onderwerpen uit de subsidietitel te behandelen, maar een selectie te maken en binnen die selectie alleen in te gaan op de hoofdlijnen en niet op allerlei detailkwesties. Wij zijn tot de selectie gekomen door enkele rond de inwerkingtreding van de subsidietitel verschenen artikelen van toonaangevende auteurs, te analyseren. ${ }^{\mathbf{6}}$ Wat waren, volgens de deskundigen toen, de belangrijkste onderdelen van de subsidietitel en welke verwachtingen hadden zij daarvan? Voor de op die wijze geselecteerde onderwerpen gaan wij na wat er in de afgelopen 15 jaar (op hoofdlijnen) in de rechtspraktijk is gebeurd, voornamelijk op basis van een analyse van de jurisprudentie. Wij behandelen deze onderwerpen kort in de paragrafen 2 tot en met 8; een meer gedetailleerde beschrijving van de stand van zaken geven wij elders, 7 het gaat ons hier om de hoofdlijnen, de trends. Kan daaruit iets worden afgeleid over het Awb-proces, dat voor de wetgever nu nog relevant kan zijn? Uit de analyse van de jurisprudentie blijkt dat er in de rechtspraktijk ook onderwerpen spelen die ten tijde van de inwerkingtreding van de subsidietitel nauwelijks of geen aandacht kregen. Meest opvallend is dat met name Europeesrechtelijk getinte onderwerpen als staatssteun en het transparantiebeginsel veel aandacht vragen, waar de regering destijds in de Memorie van Toelichting aan een A4 genoeg had om de verhouding met 'het gemeenschapsrecht' uit te leggen. Ook de (indringendheid van de) toetsing van de evenredigheid van sancties in het licht van artikel 6 EVRM bleek in de rechtspraktijk een veel groter punt te worden dan de wetgever had voorzien. Deze onderwerpen bespreken wij in paragraaf 9; het is immers ook interessant om te bezien welke kwesties de Awb-wetgever over het hoofd zag destijds. Wat kunnen wij daarvan leren voor de voortzetting van het Awb-project?

In de paragrafen 10 en 11 gaan we vervolgens in op enkele recente ontwikkelingen in het subsidiebeleid: de wens de uitvoeringslasten te beperken, het idee om een horizonbepaling op te nemen in (vrijwel) alle subsidieregelingen en de noodzaak van evaluatie van subsidieregelingen. Nadat we aldus hebben besproken wat in 1998 belangrijk was in de discussie rond de subsidietitel en wat daarna belangrijk werd in de subsidiewetgeving en jurisprudentie, richten wij de blik vooruit. Wat zal wellicht belangrijk worden in het subsidierecht in de nabije toekomst? En zijn we op die ontwikkelingen, met de subsidietitel (en de rest van de Awb) in de hand, voldoende voorbereid? Wij sluiten deze bijdrage af met een slotbeschouwing waarin we ingaan op de vraag in hoeverre de doelstellingen die de wetgever had bij het ontwerpen van de subsidietitel zijn bereikt en waarin we onze verwachtingen uitspreken over de ontwikkeling van het subsidierecht in de komende vijftien jaar. Om de doelstellingen van de wetgever met de subsidietitel weer helder op het netvlies te krijgen volgt daarover eerst een korte uiteenzetting. 
Uiteraard golden de algemene uitgangspunten van de wetgever bij het ontwikkelen van algemene regels van bestuursrecht, ook bij de totstandkoming van de subsidietitel. Deze moest dus in het algemeen zorgen voor meer eenheid binnen het subsidierecht, het systematiseren en zo mogelijk vereenvoudigen daarvan en de codificatie van in de jurisprudentie ontwikkelde leerstukken. ${ }^{\mathbf{8}}$ In de algemene toelichting op de subsidietitel vinden we wat specifiekere doelstellingen. ${ }^{9}$ De regering benadrukt daarin dat gezien de omvang van de subsidie-uitgaven de tijd is gekomen daarvoor een wettelijke grondslag te verlangen. Verder zou onduidelijkheid over rechten en plichten van subsidieontvangers regelmatig leiden tot gerechtelijke procedures. Met een algemene wettelijke regeling zou de rechtszekerheid binnen subsidierelaties worden versterkt en daarmee de doelmatigheid en doeltreffendheid van het subsidie-instrument. Tot slot - en dat paste geheel in de tijdsgeest van de jaren waarin de titel tot stand kwam (en eigenlijk ook heel aardig in de huidige tijdsgeest) - zou een wettelijke regeling een belangrijke bijdrage moeten leveren aan de beheersing van de overheidsuitgaven aan subsidieregelingen en het tegengaan van misbruik van subsidiegelden.

Nogal wat doelstellingen dus voor een regeling met een zeer breed bereik. Dat is ook te zien in het resultaat: de subsidietitel geeft een eenduidig begrippenkader voor het subsidierecht, waarmee bestaande, zeer diverse wettelijke kaders vrij rigoureus werden geharmoniseerd. Tegelijkertijd begreep de wetgever ook dat een regeling met zo een breed bereik de nodige flexibiliteit moest bieden. Steeds is geprobeerd rekening te houden verschillende vormen van subsidies en verschillende beleidsterreinen, met als gevolg een grote hoeveelheid bepalingen, met daaronder veel semi-dwingende bepalingen, waarvan bij wettelijk voorschrift kan worden afgeweken en facultatieve bepalingen. Dat heeft wel tot kritiek geleid: de Raad van State noemde het werkstuk bijvoorbeeld "topzwaar" en adviseerde het werk geleidelijk in te voeren. ${ }^{\mathbf{1 0}}$ De regering meende echter dat in dat geval de beoogde rechtseenheid niet snel genoeg zou worden bereikt. ${ }^{\mathbf{1 1}}$ Het was de wetgever ernst met die doelstelling, dus trad op 1 januari 1998 de regeling in haar geheel in werking.

\section{Subsidiebegrip}

Een belangrijke harmoniserende bepaling, die destijds aanleiding gaf tot de nodige discussie, betreft de algemene, wettelijke definitie van de subsidie. De wetgever beoogde met titel 4.2 Awb een wettelijke kader te geven voor alle subsidieregelingen waarmee de overheid bepaalde wenselijk geachte activiteiten financieel ondersteunt c.q. stimuleert. ${ }^{12}$ Daarom bepaalt artikel 4:21 Awb, eerste lid, dat 'onder subsidie wordt verstaan: de aanspraak op financiële middelen, door een bestuursorgaan verstrekt met het oog op bepaalde activiteiten van de aanvrager, anders dan als betaling voor aan het bestuursorgaan geleverde goederen of diensten.'

Het betreft een zogenaamde materiële definitie. Alle financiële verstrekkingen van overheidswege die voldoen aan deze begripsomschrijving zijn subsidies, ongeacht hun benaming, zo merkt de regering uitdrukkelijk op in de Memorie van Toelichting bij de subsidietitel. ${ }^{\mathbf{1 3}}$ Dat betekent dat sprake is van een subsidie wanneer aan de definitie-elementen is voldaan, ook wanneer de verstrekking anders (bijvoorbeeld als tegemoetkoming, financiering, bijdrage of opdracht) wordt aangeduid. ${ }^{\mathbf{1 4}}$ Dat klinkt gemakkelijker dan het in de praktijk is gebleken. De bijzondere regelgevers en bestuursorganen blijken het soms behoorlijk ingewikkeld te maken. Wij vonden verschillende uitspraken waarin financiële bijdragen ter discussie stonden waarin de regelgever deze geen subsidie noemde 
of het verstrekkende bestuursorgaan bij hoog en bij laag volhield dat het geen subsidie betrof. ${ }^{\mathbf{1 5}}$ Eén van de oorzaken is dat veel ministers er geen been in zien om werkzaamheden die 'in wezen' tot de overheidstaak behoren, uit te besteden aan stichtingen en hen daarvoor een zak geld te geven. De reden daarvoor ligt vaak in politieke gevoeligheden. De Minister kan de ziektekosten van illegalen niet betalen binnen het huidige vreemdelingenbeleid, maar hij kan wel een stichting oprichten die de kosten van zorginstellingen die noodhulp verlenen aan deze groep (deels) compenseert. ${ }^{\mathbf{1 6}}$ Wanneer er op die manier een door de overheid gefinancierde, geld uitdelende stichting ontstaat, rijst al snel de vraag of deze stichting subsidies verstrekt en bij geschillen dus de rechtsgang naar de bestuursrechter open staat.

Deze vrij technische jurisprudentie ${ }^{\mathbf{1 7}}$ is interessant in het kader van de discussie over de 'publieke taak jurisprudentie', maar in deze bijdrage is een uitgebreide bespreking niet nodig. Volstaan kan worden met de constatering dat de doelstellingen van de wetgever (rechtszekerheid, harmonisatie) op een vrij structurele manier worden ondergraven door de regelgever en het bestuur. Die hebben soms goede reden om een financiële verstrekking niet als subsidie te (willen) beschouwen, met alle ingewikkelde discussies die daarna ontstaan, als in een concreet geschil het wettelijk kader moet worden vastgesteld, van dien. Het komt ook voor dat wet- en regelgever goede redenen hebben om een financiële verstrekking wél als subsidie te kwalificeren, terwijl zij dat eigenlijk niet is. Wij zien dat bijvoorbeeld gebeuren bij opdrachten die worden verstopt in een subsidie, in een poging het aanbestedingsrecht te ontwijken en bij schadevergoedingen die op grond van de toepasselijke wetgeving eigenlijk niet zijn toegestaan. Een subsidie op grond van ruim geformuleerde kaderwetgeving kan in dat laatste geval uitkomst bieden voor een politicus die onder druk wordt gezet om 'iets te doen' voor 'schrijnende gevallen'. Zo kon het voorkomen dat er 'subsidies' werden verstrekt voor misgelopen inkomsten aan pomphouders in de grensstreek, aan pluimveehouders die werden getroffen door een

vervoersbeperkingsgebied in verband met de vogelgriep en aan landbouwers met regenschade. Ook hier volgde op punten ingewikkelde en weinig overtuigende jurisprudentie, ${ }^{\mathbf{1 8}}$ die illustreert dat de wens om te komen tot eenvoudiger subsidierecht soms door de waan van de dag uit het oog wordt verloren. En ook dat het voor de bestuursrechter niet altijd eenvoudig is om in zulk soort gevallen aan de wens van de wetgever te voldoen en de regels van de subsidietitel onverkort toe te passen. Het geschil moet immers worden beslecht en met de conclusie dat een verstrekking geen subsidie in de zin van artikel 4:21 Awb is, vervallen ook vaak de bevoegdheidsgrondslag en het toepasselijk wettelijk kader, met totale juridische wanorde als gevolg.

Maar vanuit het streven naar harmonisatie en vereenvoudiging is waarschijnlijk nog een groter probleem dat de wetgever al in artikel 4:21 Awb een aantal belangrijke uitzonderingen heeft opgenomen. Daardoor is de subsidietitel bijvoorbeeld niet van toepassing op fiscale stimuleringsmaatregelen, die hun eigen fiscale systematiek en rechtsbescherming kennen. Daar is de harmonisatie dus beperkt, zoals dat vaak geldt in fiscalibus. ${ }^{\mathbf{1 9}}$ In de praktijk zijn subsidiëring en fiscale stimulering echter nauwelijks uit elkaar te houden. ${ }^{\mathbf{2 0}}$ Zo worden belangrijke fiscale regelingen op het gebied van innovatieve activiteiten van ondernemingen (de $\mathrm{WBSO}^{\mathbf{2 1}}$ en de $\mathrm{RDA}^{\mathbf{2 2}}$ ) uitgevoerd door Agentschap NL, hét onderdeel van de rijksoverheid gespecialiseerd in subsidieverstrekking en is de voor de praktijk zo lucratieve Innovatiebox daaraan direct gekoppeld. ${ }^{\mathbf{2 3}}$ Een tweede belangrijke uitzondering betreft de onderwijsbekostiging; daarop is de subsidietitel blijkens artikel 4:21 Awb, vierde lid, slechts van 'overeenkomstige toepassing'. Op dat punt kwam al tijdens de totstandkomingsfase in de literatuur 
veel kritiek. ${ }^{\mathbf{2 4}}$ Gelukkig is uit de jurisprudentie inmiddels gebleken dat dat doorgaans betekent dat het algemene subsidierecht op onderwijsbekostiging gewoon (aanvullend) van toepassing is, ${ }^{\mathbf{2 5}}$ maar in de praktijk leidt de bepaling nog regelmatig tot verwarring en geschillen. ${ }^{\mathbf{2 6}}$

De (fiscale en onderwijs)uitzonderingen ondergraven de harmonisatiedoelstelling van de Awb-wetgever op ernstige wijze. Omvangrijke financieringsstromen vallen door de subsidiedefinitie, en dan vooral de uitzonderingen daarop, buiten de reikwijdte van de subsidietitel, terwijl er goede argumenten kunnen worden aangevoerd waarom de subsidietitel daarop wel van toepassing zou moeten zijn. Steun voor de stelling dat zo omvangrijke financieringsstromen buiten beeld blijven, kan worden ontleend aan de verschillende subsidieoverzichten die het Rijk de afgelopen jaren het licht heeft doen zien. ${ }^{\mathbf{2 7}}$ In de verschillende subsidieoverzichten werden steeds verschillende subsidiedefinities gehanteerd. Toen in 2010 voor het eerst de Awb-definitie werd gehanteerd werd er door het Rijk plotseling "nog maar" 6 miljard euro aan subsidies uitgegeven, terwijl in 2003 en 2006 veel hogere bedragen werden gerapporteerd op basis van definities van het begrip subsidie die nog van voor de inwerkingtreding van de subsidietitel dateerden. ${ }^{\mathbf{2 8}}$ Zo werd er volgens het SOR 2003 dat jaar ongeveer 22 miljard euro aan subsidies gespendeerd en volgens het Instrumentenoverzicht Rijk in 2006 ongeveer 89 miljard euro aan "subsidies en overdrachten”. ${ }^{29}$ In 2003 hanteerde men een definitie uit de Miljoenennota uit 1988, in 2006 een definitie uit het ESR 1995. ${ }^{\mathbf{3 0}}$ Maar wellicht is er hoop: het Ministerie van OC\&W heeft laten onderzoeken hoe het bekostigingsrecht beter kan aansluiten op het algemene subsidierecht: ${ }^{\mathbf{1 1}}$ Zie daar een belangrijke, vrijwillige beweging richting meer eenheid in het subsidierecht.

\section{De wettelijke grondslag}

De wetgever maakte een principiële keuze door in artikel 4:23 Awb te bepalen dat subsidieverlening op een wettelijke grondslag diende te berusten. In de literatuur was daar al voor gepleit door bijvoorbeeld Damen en Hirsch Ballin, ${ }^{\mathbf{2}}$ tegen de in vroeger tijden heersende leer in dat voor subsidies geen grondslag in de wet vereist is omdat de overheid daarmee slechts een "gunst" verleent. 33 Desalniettemin is tijdens de voorbereiding van de subsidietitel, die begon met de publicatie van het voorontwerp in 1993, en na de inwerkingtreding van titel 4.2 welwillend gereageerd op artikel 4:23. Er werd wel voor gewaarschuwd dat bestuursorganen om aan artikel 4:23 te voldoen wel eens voor heel ruime grondslagen zouden kunnen kiezen, waarmee de rechtszekerheid voor (potentiële) subsidieontvangers noch de doelmatige afwikkeling van de subsidie gediend zouden zijn. Ook werd gewezen op de werklastverzwaring voor bestuursorganen doordat zij hun subsidies (binnen vier jaar na de inwerkingtreding van de subsidietitel) van een wettelijke grondslag moesten voorzien. ${ }^{\mathbf{3 4}}$ Kennelijk was de tijd rijp voor de verplichting dat subsidieverleningen voortaan op een grondslag in een wettelijk voorschrift moesten berusten. Bovendien bevatte artikel 4:23 een aantal uitzonderingen, waardoor het toch mogelijk bleef om in spoedeisende of incidentele gevallen subsidie te verstrekken zonder dat daarvoor eerst een grondslag in een wettelijk voorschrift behoeft te worden gecreëerd. In beide gevallen is de bevoegdheid wel ingekaderd. Bij spoedeisende subsidies moet er wel binnen een jaar na de aanvang van de subsidiëring een subsidieregeling tot stand zijn gekomen (of als het om een wet in formele zin gaat - een wetsvoorstel bij de Staten-Generaal zijn ingediend) terwijl bij incidentele subsidies de eis wordt gesteld dat een dergelijke subsidie voor ten hoogste vier jaar mag worden verstrekt omdat er 
anders uiteraard geen sprake meer is van een incident. Ook geldt er een uitzondering voor begrotingssubsidies. Voorwaarde is dan wel dat de begroting van het bestuursorgaan dat de subsidie verstrekt de naam van de ontvanger vermeldt en ook het maximale bedrag dat hij ontvangt. Ten slotte bevat artikel 4:23 een uitzondering voor Europese subsidies. Op subsidies die de Europese Commissie of een ander EU-orgaan rechtstreeks aan een eindontvanger verstrekt is de Awb en dus ook de eis van een wettelijke grondslag niet van toepassing.

De stand van de jurisprudentie geeft aanleiding te denken dat het vereiste van een wettelijke grondslag in de praktijk tot niet al te grote problemen aanleiding heeft gegeven. Er zijn wat uitspraken over de vraag wat het rechtsgevolg moet zijn als een toereikende wettelijke grondslag ontbreekt. In dat geval is het bestuursorgaan niet bevoegd subsidie te verstrekken. Heeft het dat toch gedaan, dan wordt de beslissing om subsidie te verstrekken gewoon als een (appellabel) besluit aangemerkt. ${ }^{35}$ De bestuursrechter toetst ambtshalve of een bestuursorgaan bevoegd is om subsidie te verlenen. Is het dat niet, dan vernietigt hij de verleningsbeschikking (wegens onbevoegdheid van het bestuursorgaan), maar laat hij in de regel de rechtsgevolgen in stand. Op deze wijze wordt voorkomen dat de burger die beroep instelt tegen zijn subsidiebeschikking omdat hij vond dat hij eigenlijk meer subsidie had moeten krijgen, er op achteruit gaat. ${ }^{\mathbf{3 6}}$ Is er evenwel beroep ingesteld door een ander dan de subsidieontvanger, dan kan de bestuursrechter dit laatste niet doen. Hij zal de rechtsgevolgen dan dus niet in stand laten als hij het besluit vernietigt; de subsidieontvanger verliest in dat geval zijn aanspraak op subsidie.

Uit de jurisprudentie van de Afdeling bestuursrechtspraak van de Raad van State en de Centrale Raad van Beroep volgt dat bestuursorganen het gebrek dat een wettelijke grondslag ontbreekt, met terugwerkende kracht mogen repareren. ${ }^{37}$ Voorwaarde is wel dat de alsnog opgestelde wettelijke regeling aanspraken die uit een reeds gegeven subsidieverleningsbeschikking voortvloeiden, niet alsnog met terugwerkende kracht mag beperken. De reden daarvoor is o.m. dat dergelijke aanspraken kunnen worden aangemerkt als eigendom in de zin van artikel 1 Eerste Protocol bij het EVRM. ${ }^{\mathbf{3 8}}$ Bij zogenaamde "doorgeefsubsidies", waarbij het Rijk een decentraal bestuursorgaan budget geeft om subsidies van aan derden te verstrekken, rust er eveneens een verplichting op decentrale bestuursorganen om in een wettelijke grondslag te voorzien. Is dat nagelaten en wordt dit later met terugwerkende kracht gerepareerd, dan draait het decentrale bestuursorgaan op voor de kosten van de subsidies die het reeds had verstrekt voordat er was voorzien in de wettelijke grondslag. 39

Op één onderdeel is artikel 4:23 Awb wel problematisch gebleken; namelijk waar het gaat om Europese subsidies. Bij Europese subsidies is veelal sprake van gedeeld bestuur: de EU bepaalt (de hoofdlijnen van) het stimuleringsbeleid, maar laat de uitvoering en soms ook de nadere invulling van het beleid over aan de lidstaten. Het gevolg hiervan is dat de lidstaten subsidies verstrekken die geheel of gedeeltelijk ten laste komen van de Europese begroting en die (mede) worden beheerst door Europese regels. Evenals wanneer het gaat om strikt nationale subsidies, moet bij Europese subsidies steeds de vraag worden beantwoord of het in een concreet geval nodig is om te voorzien in een grondslag in een wettelijk voorschrift.

Als subsidies worden verstrekt op grond van een Unieverordening, dan zijn er althans in theorie - twee mogelijkheden: de bevoegdheid van het Nederlandse bestuursorgaan dat de Uniesubsidies in Nederland moet gaan verstrekken volgt uit de verordening of de verordening verwijst slechts naar "de bevoegde autoriteiten”. Het eerste geval doet zich bij ons weten niet voor, ${ }^{40}$ maar als het 
zich voordoet is de bevoegdheid van het bestuursorgaan een gegeven. Aan artikel 4:23, eerste lid, is dan voldaan (ook al is dat eigenlijk niet relevant omdat de Europese verordening rechtstreeks werkt in de Nederlandse rechtsorde en aan het nationale bevoegdheidsrecht dan verder geen betekenis toekomt). Het tweede geval is eigenlijk het normale geval. De verordening richt zich tot de bevoegde autoriteit(en) in de lidstaat, maar regelt niet welk orgaan van de lidstaat de bevoegde autoriteit is. In dergelijke gevallen is het nationale recht wel van toepassing, en dus ook artikel 4:23 dat de aanwijzing van het bevoegd gezag in een wettelijk voorschrift vereist. In dergelijke gevallen worden er als het ware twee bevoegdheidsgrondslagen gevraagd: een in het Europese recht en een in het nationale recht. Er wordt in verband hiermee dan ook wel gesproken van de leer van de dubbele bevoegdheidsgrondslag. ${ }^{\mathbf{4 1}}$ Hoewel deze leer steun vindt in de Nederlandse subsidiejurisprudentie, ${ }^{\mathbf{4 2}}$ is zij in de literatuur wel betwist en zijn er inmiddels verschillende arresten van het Hof van Justitie EU beschikbaar waaruit kan worden opgemaakt dat het Hof het vooral pragmatisch bekijkt. ${ }^{\mathbf{4 3}}$ Zeker in handhavingskwesties geldt dat het Hof aanneemt dat nationale uitvoeringsorganen steeds bevoegd zijn om de nodige terugvorderingsbesluiten te nemen, desnoods rechtstreeks op basis van de Europese verordeningen zelf. In de Nederlandse jurisprudentie is verder veel te doen geweest over artikel 4:23, derde lid, onderdeel b. Op grond van deze bepaling geldt het vereiste van een wettelijke grondslag niet "indien de subsidie rechtstreeks op grond van een door de Raad van de Europese Unie, het Europees Parlement en de Raad gezamenlijk of de Europese Commissie vastgesteld programma wordt verstrekt”. Voor deze uitzondering werden destijds twee redenen gegeven: ten eerste zou een nationale wettelijke regeling een doublure opleveren omdat de Europese programma's de voorwaarden waaronder de subsidies konden worden verstrekt reeds regelden en ten tweede zou met het opstellen van nationale wettelijke regelingen kostbare tijd verloren gaan waardoor Nederland niet of met vertraging kon profiteren van EU-subsidies. ${ }^{\mathbf{4 4}}$ Het probleem met dit onderdeel van het derde lid van artikel 4:23 is, kort gezegd, dat niet duidelijk is wat precies wordt bedoeld met subsidies die rechtstreeks op grond van een Europees programma worden verstrekt. Dit is niet alleen gesignaleerd in de literatuur, $\mathbf{4 5}$ maar blijkt ook uit het feit dat de hoogste bestuursrechters deze bepaling verschillend hebben uitgelegd. ${ }^{\mathbf{4 6}} \mathrm{Er}$ is dan ook voor gepleit om dit onderdeel van artikel 4:23, derde lid, te laten vervallen. ${ }^{47}$ De reden daarvoor is overigens niet alleen dat de bepaling niet duidelijk is, maar ook dat zij overbodig lijkt. Het in de memorie van toelichting genoemde bezwaar dat het tijdrovend is om een nationale wettelijke regeling op te stellen, is niet erg steekhoudend doordat er op vrijwel alle beleidsterreinen kaderwetgeving is die voldoende ruimte biedt om de Europese programma's te implementeren. Een belangrijke voorlopige conclusie is derhalve dat, hoewel de Europese aspecten van het subsidierecht belangrijk zijn gebleken de afgelopen jaren (daarover hierna meer), datgene wat de Awbwetgever erover heeft geregeld de rechtspraktijk niet heeft geholpen.

\section{Verdeelsystematiekbij subsidieplafond en begrotingssubsidie}

Afdeling 4.2.2 Awb geeft een summiere regeling van het zogenaamde subsidieplafond. ${ }^{\mathbf{4 8}}$ In het kort houdt deze regeling in dat een bestuursorgaan in beginsel voordat het subsidietijdvak begint - een subsidieplafond kan instellen en dat aanvragen worden geweigerd als door subsidieverstrekking het plafond zou worden overschreden of als het al is overschreden. Van der Vlies noemde het subsidieplafond destijds de beruchtste van de tamelijk ingewikkelde 
nieuwigheden uit titel 4.2.49 Ook over de verdeling van het beschikbare budget is de Awb kort. Artikel 4:26 bepaalt slechts dat bij of krachtens wettelijk voorschrift wordt bepaald hoe het beschikbare bedrag wordt verdeeld (eerste lid) en bij de bekendmaking van het subsidieplafond wordt de wijze van verdeling vermeld (tweede lid). Uit de memorie van toelichting kan worden afgeleid dat de wetgever vond dat wat het meest geschikte verdeelsysteem is, afhankelijk is van de soort subsidie die moet worden verdeeld.$^{50}$ De Awb regelt dus niet welk verdeelsysteem van toepassing is, maar slechts dát er een verdeelsysteem wordt gekozen. In de memorie van toelichting werd alleen melding gemaakt van de verdeling op volgorde van binnenkomst en de verdeling op grond van kwalitatieve criteria. ${ }^{\mathbf{5 1}}$ De jurisprudentie en de regelgeving laten zien dat er nog andere verdeelsystemen, zij het in mindere mate, worden gebruikt. ${ }^{\mathbf{2}}$ Opvallend is dat er in de afgelopen vijftien jaar veel jurisprudentie is gewezen over de verdeling van het beschikbare subsidiebudget. Als de verdeling van een subsidie verloopt volgens de systematiek "wie het eerst komt, het eerst maalt", gaan procedures vaak over de vragen: wie was eerst, moet de aanvraag van iemand die een onvolledige aanvraag indiende buiten beschouwing worden gelaten of niet, mag een eenmaal ingediende aanvraag nog worden gewijzigd en hoe wordt de volgorde van indiening bepaald als er op de eerste dag dat kan worden ingediend een (te) groot aantal aanvragen tegelijk wordt ingediend?53 Als de subsidie in een tenderprocedure wordt verdeeld spelen in de jurisprudentie twee vragen een belangrijke rol: 1 . de vraag of aanvragers gelijke kansen hebben gekregen en 2. de vraag of de (uitkomst van de) procedure inzichtelijk was. Bij de eerste vraag gaat het om discussies over de vraag of een (volledige of onvolledige) aanvraag nog mag worden aangevuld na afloop van de indieningstermijn en of er contact mag zijn tussen bestuursorgaan een aanvrager. Bij discussies over de inzichtelijkheid en de uitkomst van de procedure gaat het om de vraag of aanvragen terecht zijn afgewezen omdat de aanvraag niet voldeed aan de criteria om voor subsidieverlening in aanmerking te komen (is voldaan aan bepaalde drempelvereisten, zoals het hebben van een bepaalde rechtsvorm, omvang, vestigingsplaats, etc.) of om vragen over de vergelijkbaarheid van de oordelen over de concurrerende aanvragen (motivering afwijzingsbesluit, toegankelijkheid van op de zaak betrekking hebbende stukken, de rol van externe adviescommissies e.d.).54 Dergelijke vraagstukken spelen niet alleen op het terrein van het subsidierecht. We zien ze terug in alle rechtsgebieden waarin sprake is van de verdeling van schaarse publieke rechten. 55 We ontwaren hier tevens een begin van Europese beïnvloeding van de verdelingsregels in het (subsidie)recht; bij de verdeling moet sprake zijn van "een voldoende mate van transparantie".56

In dit kader is het ook van belang te wijzen op een andere "verdeelmethode" die de Awb kent, maar die volledig losstaat van het subsidieplafond (en die daarmee tijdens de wetsgeschiedenis ook nooit in verband is gebracht): de begrotingssubsidie. ${ }^{57}$ Bestuursorganen kunnen ervoor kiezen het beschikbare subsidiebudget aan een of enkele (voorkeurs)partijen toe te kennen door die partij(en) en het maximale subsidiebedrag te noemen in hun begroting. Een grondslag in een wettelijk voorschrift is dan niet nodig (art. 4:23, derde lid, onder c, Awb). De wetgever vond deze uitzondering gerechtvaardigd omdat er bij begrotingssubsidies vaak maar één of enkele ontvangers zijn. Het totstandbrengen van een wettelijke grondslag zou dan "een relatief zware last voor de bevoegde wetgever betekenen, terwijl (...) de noodzaak daartoe in mindere mate aanwezig is indien de begroting de ontvanger vermeldt" $5^{8}$ Het nadeel dat, bij slechts op een begrotingspost gebaseerde subsidie, wettelijke 
voorschriften, die de verhouding tussen subsidieverstrekker en -ontvanger verder regelen, ontbreken, zou worden ondervangen doordat veel artikelen uit de afdelingen 4.2.2 tot en met 4.2.7 sowieso op de subsidieverhouding van toepassing zijn en doordat bij exploitatiesubsidies afdeling 4.2.8 van toepassing zou kunnen worden verklaard.59 Een ander en steeds zwaarder wegend nadeel is door de wetgever echter niet onder ogen gezien. Ook bij begrotingssubsidies wordt subsidiebudget verdeeld; deze verdeling is echter minder transparant dan wenselijk is. Zo is niet duidelijk wie aanspraak kan of kunnen maken op bepaalde subsidiegelden en in welke gevallen de overheid direct met een voorkeurspartij in zee kan gaan. Nieuwkomers lijken in ieder geval op achterstand te staan. ${ }^{\mathbf{6 0}} \mathrm{Bij}$ het uitzetten van Europese subsidies is het overigens niet mogelijk om op een dergelijke intransparante manier te werk te gaan ${ }^{\mathbf{6 1}}$ en dat geeft te denken.

Inmiddels is de jurisprudentie over de verdeling van subsidiebudgetten zover uitgekristalliseerd dat een wat uitgebreidere regeling in afdeling 4.2.2 Awb naar onze mening in de rede zou liggen. In een artikel in JBplus hebben wij ervoor gepleit om in artikel 4:26, eerste lid, de verdeelmethoden toe te voegen en om twee nieuwe artikelen in te voegen waarin de vaste jurisprudentie over de meest gebruikte verdeelmethoden worden gecodificeerd (artikel 4:26a over de verdeling op volgorde van binnenkomst en artikel 4:26b over verdeling bij tenderprocedures). De keuze voor een bepaalde verdeelmethode ligt dan nog steeds bij de (lagere) wetgever of het bestuursorgaan, maar bepaalde met de keuze voor subsidiëren op volgorde van binnenkomst of een tenderprocedure samenhangende regels liggen dan tenminste duidelijk vast. ${ }^{\mathbf{6 2}}$ Gelet op het feit dat dit onderwerp, zoals wij hiervoor al aangaven, veel breder speelt, zou een dergelijke regeling ook als proeftuin kunnen fungeren voor een algemene regeling in de Awb over verdelingsvraagstukken. Tot slot lijkt het ons wenselijk dat in dat kader ook nog eens wordt nagedacht over (de beperking van de mogelijkheid tot het verstrekken van) begrotingssubsidies.

\section{De uitvoeringsovereenkomst}

Over de rechtsvorm van de subsidie is in de literatuur ten tijde van inwerkingtreding van de subsidietitel en kort daarna veel discussie geweest. De wetgever heeft er in de subsidietitel voor gekozen om in de eerste plaats regels te geven voor subsidiebeschikkingen. Deze keuze sloot aan bij de jurisprudentie. Die merkte de verlening van subsidies vrijwel altijd aan als een beschikking, ook wanneer zij niet op een geschreven publiekrechtelijke grondslag berustte, maar op een begrotingspost. ${ }^{63}$ Omdat in de praktijk ook "overeenkomsten omtrent subsidiëring" $\mathbf{6 4}$ voorkwamen, werd ook een artikel in de subsidietitel gewijd aan het fenomeen subsidieovereenkomst. In het voorontwerp ging dit artikel er nog van uit dat de subsidieverlening de vorm van een overeenkomst tussen subsidieverstrekker en -ontvanger kon hebben. Omdat er in die variant geen verleningsbeschikking aan de subsidieverhouding te pas kwam werd deze figuur al gauw aangeduid met de term 'beschikkingvervangende overeenkomst'. Op het artikel kwam echter veel kritiek en toen de Raad van State suggereerde het artikel zodanig te wijzigen dat ter uitvoering van de verleningsbeschikking een overeenkomst kon worden gesloten, was de wetgever snel om: de beschikkingvervangende overeenkomst maakte plaats voor de uitvoeringsovereenkomst. Het artikel regelt niet alleen dat ter uitvoering van een subsidieverleningsbeschikking een overeenkomst kan worden gesloten (eerste lid), maar ook dat in deze overeenkomst kan worden bepaald dat de ontvanger 
verplicht is de gesubsidieerde activiteiten de verrichten (tweede lid). ${ }^{\mathbf{6 5}}$ Hoewel ook de figuur van de uitvoeringsovereenkomst is bekritiseerd, ${ }^{\mathbf{6 6}}$ en interessant is als verschijnsel waar publiek- en privaatrecht in elkaar overlopen, kunnen we 15 jaar na de inwerkingtreding constateren dat er nauwelijks jurisprudentie is over dit artikel. ${ }^{67}$ In 2006 oordeelde de Afdeling bestuursrechtspraak dat titel 4.2 zich verzet tegen beschikkingvervangende subsidieovereenkomsten. ${ }^{\mathbf{6 8}}$ Daarnaast is er enige jurisprudentie over de vraag welke rechter geschillen over de uitvoeringsovereenkomst moet beoordelen; de burgerlijke rechter of de bestuursrechter. ${ }^{\mathbf{6 9}}$ Voorts hebben zowel het $\mathrm{CBb}$ als de Afdeling bestuursrechtspraak uitspraak gedaan over de vraag of een subsidieverstrekker bevoegd was tot intrekking van subsidie omdat de ontvanger een in de uitvoeringsovereenkomst neergelegde verplichting niet was nagekomen. Het antwoord was ja. ${ }^{\mathbf{7 0}}$ Tot slot is er een kleine reeks uitspraken te noemen over de verstrekking van zgn. BIZ-subsidies aan rechtspersonen met wie op grond van de Experimentenwet BI-zones een zgn. afdwingovereenkomst op grond van artikel 4:36, tweede lid, Awb moet worden gesloten. Kort gezegd kunnen gemeenteraden op grond van deze wet onder de naam BI-zone een heffing instellen binnen een bepaald gebied in de gemeente (de zogenaamde bedrijveninvesteringszone). De gemeente betaalt de opbrengst van de heffing als subsidie door aan een bij verordening aangewezen rechtspersoon, die het geld uitgeeft aan activiteiten waarvan alle in de BI-zone gelegen ondernemingen voordeel van hebben, zoals het verbeteren van de bewegwijzering, graffitiverwijdering en extra surveillance. Deze jurisprudentie heeft echter niet zozeer betrekking op de betekenis van artikel 4:36 (tweede lid), als wel op de verbindendheid van verordeningen die op grond van de Experimentenwet BIzones tot stand zijn gekomen. Artikel 7 van deze wet bepaalt namelijk dat de subsidieontvanger in de verordening aangewezen moet worden en dat met de subsidieontvanger een overeenkomst moet zijn gesloten als bedoeld in artikel 4:36 lid 2 Awb. Uit de jurisprudentie volgt dat de BIZ-verordening in zijn geheel onverbindend is als blijkt dat op het moment van de heffing met de in de verordening aangewezen subsidieontvanger geen (duidelijke) afdwingovereenkomst is gesloten..$^{\mathbf{1}}$

Terugblikkend op de discussies voor de inwerkingtreding van de subsidietitel en de weinige jurisprudentie sinds de inwerkingtreding, is het lastig een conclusie te trekken over het fenomeen uitvoeringsovereenkomst; is het goed geregeld omdat er weinig jurisprudentie en discussie over is of worden er eenvoudigweg weinig uitvoeringsovereenkomsten gesloten? Wij zouden het niet weten.

\section{Handhavingsmogelijkheden en evenredigheid, boete}

Aan het tegengaan van fraude met subsidies werd aardig wat aandacht besteed tijdens de totstandkoming van de subsidietitel. Volgens de Memorie van Toelichting ging het daarbij om twee hoofdpunten: misbruik van subsidiegelden en het niet nakomen van verplichtingen door de subsidieontvanger. De subsidietitel biedt allerlei mogelijkheden aan bestuursorganen om te reageren op ‘onregelmatigheden' aan de kant van de subsidieontvanger.

Subsidiebeschikkingen kunnen in dat geval worden ingetrokken of ten nadele van de subsidieontvanger worden gewijzigd, de subsidie kan lager worden vastgesteld en onverschuldigd betaalde subsidies kunnen worden teruggevorderd. ${ }^{\mathbf{2}}$ Het betreft hier allemaal bestuursrechtelijke sancties. De Awb-wetgever gaf aan dat het natuurlijk in sommige gevallen ook mogelijk was om via strafrechtelijke weg te handhaven, bijvoorbeeld op grond van valsheid in geschrifte. Verder werd aangekondigd dat er in het kader van de vierde tranche 
van de Awb zou worden onderzocht of het mogelijk was de bevoegdheid tot het opleggen van een bestuurlijke boete in de subsidietitel op te nemen voor fraudegevallen. ${ }^{73}$

In de jurisprudentie die volgde na inwerkingtreding van de subsidietitel is aanvankelijk druk gediscussieerd over het karakter van de subsidiesancties die op grond van de titel konden worden opgelegd. Vooral als de aanspraak op subsidiegelden verder werd verminderd in geval van onregelmatigheden dan strikt genomen nodig zou zijn kwam de vraag op of er geen sprake was van een punitieve sanctie. Met name de Afdeling bestuursrechtspraak voer daarbij een straffe koers: het intrekken van subsidiebeschikkingen of het lager vaststellen van de subsidie werd in dat soort gevallen steevast als een herstelsancties gekwalificeerd: de subsidieontvanger had, achteraf bezien, niet voor subsidie in aanmerking mogen komen, zo lijkt de redenering. ${ }^{\mathbf{4 4}}$ Dat wil niet zeggen dat deze besluiten altijd in stand blijven; in een enkel geval worden deze herstelsancties toch vernietigd wegens een motiveringsgebrek of strijd met het evenredigheidsbeginsel. Het gaat dan vrijwel altijd om gevallen waarin ook kritiek kan worden geleverd op het optreden van de subsidieverstrekker zelf: die heeft een subsidieregeling bijvoorbeeld te laat inwerking doen treden of de subsidieontvanger zelf op het verkeerde been gezet. ${ }^{75}$ Het College van Beroep voor het bedrijfsleven laat het karakter van subsidiesancties meer in het midden, maar toetst regelmatig zoals het gewend is te doen bij bestuurlijke boeten. ${ }^{\mathbf{7 6}}$ Terugkomend op de bestuurlijke boete binnen subsidierelaties; de bevoegdheid daartoe is tot op de dag van vandaag niet geregeld in de Awb. Vreemd genoeg is de bevoegdheid tot het opleggen in sommige (nogal willekeurig gekozen) gevallen inmiddels wel neergelegd in de Wet bestuurlijke boete meldingsplichten door ministers verstrekte subsidies. ${ }^{77}$ Wanneer de subsidieontvanger heeft verzuimd te melden dat de activiteiten waarvoor hij subsidie kreeg niet voor een bepaalde einddatum geheel zijn verricht, voorschotten onvoldoende snel worden uitgegeven of er omstandigheden zijn die doen vermoeden dat er dwang- of kinderarbeid komt kijken bij gesubsidieerde activiteiten in het buitenland, kan dat leiden tot het opleggen van boeten tot maximaal 78.00o euro (vijfde categorie van art. 23, vierde lid, WSr). Er zijn veel vragen te stellen rondom deze wet. Waarom is de boetebevoegdheid beperkt tot situaties waarin een minister subsidie verstrekt? Waarom is er slechts een boetebevoegdheid wanneer bepaalde meldplichten niet worden nagekomen en niet in andere situaties, bijvoorbeeld de situatie waarin een bestuursorgaan ten tijde van de subsidievaststelling (ernstige) onregelmatigheden vaststelt? En misschien nog wel de belangrijkste vraag: waarom is deze regeling niet opgenomen in de Awb? De memorie van toelichting is niet helder op deze punten en al met al verdient de regeling beslist geen schoonheidsprijs; zij laat zien dat het bijzonder lastig blijft om de eenheid van het bestuursrecht vast te houden, ook als het gaat om bestuursrechtelijke wetgeving met een algemeen (ministerie-overstijgend) karakter.

\section{Beëindiging subsidierelaties}

Als laatste van de onderwerpen die ten tijde van de totstandkoming van de subsidietitel de aandacht trokken in de literatuur, bespreken wij de bepalingen die gelden bij de beëindiging van subsidierelaties wegens gewijzigde inzichten of omstandigheden. Het gaat doorgaans om (verkapte) bezuinigingen. De subsidietitel geeft daarvoor twee bepalingen, opgenomen in de artikelen 4:50 en 4:51 Awb. Artikel 4:50 Awb ziet op het intrekken van lopende subsidiebeschikkingen en voorziet daarom (terecht) in een plicht tot het 
vergoeden van dispositieschade. Misschien is dat de reden waarom er in de praktijk maar weinig van die mogelijkheid gebruik wordt gemaakt; wij zien althans nauwelijks jurisprudentie over deze bepaling.

Dat ligt heel anders voor artikel 4:51 Awb. In deze bepaling is neergelegd dat een langdurige subsidierelatie in bepaalde gevallen slechts mag worden stopgezet met inachtneming van een redelijke termijn. Deze bepaling vormde een codificatie van de vaste jurisprudentie van de Afdeling bestuursrechtspraak waarin was opgenomen dat een langdurige subsidierelatie niet 'rauwelijks mag worden stopgezet'. ${ }^{78}$ In de memorie van toelichting koppelde de regering deze bepaling nadrukkelijk aan het vertrouwensbeginsel, wat van artikel 4:51 Awb een heel aardige pilot maakt voor een eventuele bredere codificatie van dat beginsel.

De formulering van artikel 4:51 Awb is vrij specifiek, wat aanleiding heeft gegeven tot de nodige interpretatie en afbakeningsvragen. Wat zijn precies 'dezelfde of in hoofdzaak dezelfde, voortdurende activiteiten'?79 Wie is 'de subsidieontvanger' in dit kader; kan dat slechts de aanvrager zijn of tellen rechtsvoorgangers ook mee? ${ }^{\mathbf{8 0}}$ Dat soort vraagstukken doet zich vaak voor bij nieuwe bepalingen, interessanter is de vaststelling dat uit de jurisprudentie blijkt dat de formulering van artikel 4:51 Awb niet aansluit bij de uitvoeringspraktijk. Daarin wordt een subsidierelatie doorgaans niet beëindigd door de afwijzing van een aanvraag voor een nieuw subsidiejaar (de situatie waarvan artikel 4:51 Awb uit gaat), maar kiezen bestuursorganen er voor om al in een zo vroeg mogelijk stadium aan te kondigen voornemens te zijn niet opnieuw subsidie te verstrekken. Dat heeft aanleiding gegeven tot de nodige technische jurisprudentie; aankondigingen hebben immers doorgaans geen rechtsgevolg en zijn dus in beginsel geen besluit. Voor het interessante rechtsvormende werk dat met name de Afdeling bestuursrechtspraak op dit vlak heeft verricht, verwijzen wij hier graag naar ander werk. ${ }^{\mathbf{8 1}} \mathrm{Hier}$ is interessanter de vraag hoe de Afdeling bestuursrechtspraak artikel 4:51 Awb heeft ingevuld; welke bescherming kan een subsidieontvanger aan dit geschreven vertrouwensbeginsel ontlenen?

Die bescherming is beperkt, zo blijkt uit de jurisprudentie. De bestuursrechter stelt keer op keer dat het enkele feit dat het bestuursorgaan zijn beleid wil wijzigen, al dan niet genoodzaakt door bezuinigingsoverwegingen, voldoende is voor een besluit om niet verder te subsidiëren; daarvoor hoeven geen bijzondere of zwaarwegende gronden aan te worden gevoerd. ${ }^{\mathbf{8 2}}$ Dat past gezien het discretionaire karakter van de meeste subsidiebevoegdheden goed bij de aard van de relatie, zo menen wij. Interessanter is de vraag hoe concreet de 'gewijzigde inzichten' van de subsidieverstrekker waarop het beëindigingsbesluit is gebaseerd moeten zijn. Geredeneerd vanuit de gedachte dat met het beëindigingbesluit de redelijke termijn voor de subsidiënt gaat lopen - een ingrijpend rechtsgevolg dus - hadden wij het niet vreemd gevonden wanneer een dergelijk besluit alleen kan berusten op (nieuw) vastgesteld beleid. Dat zou als voordeel hebben gehad dat de bestuursrechter vervolgens ook een concreet handvat heeft om het beëindigingbesluit aan te toetsen. De Afdeling bestuursrechtspraak oordeelde daar echter anders over: het voornemen om het beleid te wijzigen is voldoende. ${ }^{\mathbf{8 3}}$ Ook bij het bewaken van de redelijke termijn blijkt de bestuursrechter niet geneigd het bestuursorgaan snel te corrigeren: wat een redelijke termijn is dient te worden vastgesteld door de subsidient zelf, waarbij beoordelingsvrijheid bestaat. De toets van de bestuursrechter is op dat vlak terughoudend. Als toetsingsmaatstaf geldt het criterium dat de subsidieontvanger voldoende tijd moet krijgen om de maatregelen te nemen om de gevolgen van de beëindiging of vermindering op een behoorlijke wijze op te 
vangen, ook jegens derden. ${ }^{\mathbf{8 4}}$ Het gaat vooral om langlopende verplichtingen die in het bijzonder zijn aangegaan in verband met de bestaande subsidierelatie. ${ }^{\mathbf{8 5}}$ De verplichting om een redelijke termijn in acht te nemen gaat uitdrukkelijk niet zover dat moet zijn gegarandeerd dat de gesubsidieerde zijn activiteiten onverkort zal kunnen voortzetten, noch dat daarmee de levensvatbaarheid van de subsidieontvanger moet zijn gegarandeerd. ${ }^{\mathbf{8 6}}$ In de jurisprudentie zien we op deze basis 'redelijke' termijnen tussen de bekendmaking van het beëindigingsbesluit en het einde van het lopende subsidietijdvak geaccordeerd worden door de rechter die wij persoonlijk nogal en soms duidelijk te kort vinden. ${ }^{\mathbf{8}}$ Daarbij speelt ongetwijfeld een rol dat, hoewel de redelijke termijn pas gaat lopen op het moment dat het beëindigingsbesluit is bekend gemaakt, eerdere mededelingen van het bestuursorgaan of zelfs andere bestuursorganen van invloed kunnen zijn op de omvang van de redelijke termijn. ${ }^{\mathbf{8 8}} \mathrm{Al}$ met al kan worden gesteld dat voormalige subsidieontvangers zelden succes hebben met hun beroep op art. 4:51 Awb, al zijn er uitzonderingen. Kennelijk bestaat er een grote discrepantie tussen wat ontvangers redelijk vinden en bestuursrechter (nog) rechtmatig.

Interessant is verder dat de bestuursrechter deze bepaling ziet als een codificatie van het vertrouwensbeginsel en bereid is deze ook buiten het directe reikwijdte van de bepaling toe te passen. ${ }^{\mathbf{8 9}}$ Dat geeft haar brede(re) bruikbaarheid weer. Artikel 4:50 en 4:51 Awb en de ervaringen die daarmee inmiddels zijn opgedaan kunnen daarmee van groot nut zijn voor de Awb-wetgever in de toekomst, bijvoorbeeld wanneer er zou worden gewerkt aan een regeling voor de intrekking van begunstigende beschikkingen, zoals eerder aangekondigd, of de algemene codificatie van het vertrouwensbeginsel. Of het zover komt moet worden afgewacht; de wetgever lijkt op dit moment weinig aandacht te hebben voor het verder bouwen aan de algemene regels van bestuursrecht.

\section{Europese aspecten}

Zoals hiervoor al aan de orde kwam blijken er in de praktijk van het subsidierecht ook onderwerpen belangrijk te zijn, waaraan de Awb-wetgever tijdens de totstandkoming van de subsidietitel in het geheel geen aandacht heeft besteed. Voor ons staat op dat lijstje de Europese dimensie van subsidieverstrekking met stip op nummer één. De Europese dimensie is, gezien de breedte en omvang van het Europese recht, nogal groot. Eerder bespraken wij al de discussie over het karakter van subsidiesancties; daarin speelt de vraag of de intrekking van subsidiebeschikkingen onder omstandigheden moet worden gezien als een criminal charge in de zin van art. 6 EVRM, c.q. een strafrechtelijke procedure waarin de waarborgen gelden van art. 48-50 Handvest van de Grondrechten van de EU, natuurlijk een belangrijke rol. ${ }^{90} \mathrm{Wij}$ benoemen in deze paragraaf slechts kort wat blijkens de jurisprudentie de grootste EU vraagstukken en knelpunten zijn in de rechtspraktijk: de uitvoering van Europese subsidieregelingen door Nederlandse bestuursorganen en het staatssteunrecht.

Europese subsidies worden al sinds lang door Nederlandse bestuursorganen worden verstrekt aan Nederlandse ontvangers. De memorie van toelichting meldt op dit punt niet veel meer dan dat deze subsidies voor zover zij op een Europese verordening berusten, al zijn voorzien van een wettelijke grondslag en dat voor zover zij berusten op een 'programma', zij zijn uitgezonderd van de eis van een wettelijke grondslag in artikel 4:23, derde lid, sub b, Awb. Die uitzondering heeft overigens voor de nodige hoofdbrekens gezorgd, zo kwam hiervoor al aan de orde. De Europese subsidieverordeningen bleken namelijk 
vaak niet de nodige bevoegdheden toe te delen aan Nederlandse bestuursorganen waardoor dan voor allerlei (al dan niet door de verordeningen vereiste) zaken (bijvoorbeeld een subsidieplafond, specifieke subsidieverplichtingen of de mogelijkheid om de subsidie per overeenkomst te verlenen) toch weer een Nederlandse regeling nodig was. Verder bleek dat de handhavingsmogelijkheden die op grond van het Europese recht zijn vereist, zich maar heel lastig in de subsidietitel lieten wringen. Kort gezegd is duidelijk geworden dat het Europese en Nederlandse subsidierecht niet goed op elkaar aansluiten. ${ }^{\mathbf{9 1}}$ Het Europese recht gaat er vanuit dat er een gelijkwaardige relatie bestaat tussen de nationale uitvoeringsorganen en de subsidieontvanger; de laatsten kiezen er vrijwillig voor subsidie aan te vragen en zijn dus te behandelen als contractspartner.92 De Awb-wetgever heeft in 1998 uitdrukkelijk gekozen voor de publiekrechtelijke rechtsbetrekking tussen bestuursorgaan en subsidieontvanger, vormgegeven in beschikkingen, met bijbehorende rechtsbescherming. Die twee verschillende uitgangspunten leiden tot andere conclusies bijvoorbeeld als het aankomt op de vraag in welke gevallen subsidieontvangers een beroep kunnen doen op het vertrouwensbeginsel en welke rechtsvorm het meest geëigend is voor subsidievertrekking. Al met al zijn er veel geschillen over Europese subsidies uitgevochten voor de Nederlandse bestuursrechter, waarbij het wettelijk kader van de subsidietitel soms eerder voor meer dan minder problemen dan in het verleden heeft gezorgd. Die problemen zijn overigens niet uniek voor de subsidiepraktijk; waar sprake is van 'gemengd bestuur' zijn er vaak afstemmingsproblemen tussen Unierecht en nationaal recht. $\mathrm{Nu}$ de uitvoeringspraktijk van het Europese subsidierecht wel het 'summum' van gemengd bestuur wordt genoemd, is het geen wonder dat dit soort problemen zich juist hier ernstig doet gevoelen. Het wekt dan ook geen verbazing dat Van den Brink onlangs, op basis van uitvoerig onderzoek waarnaar wij hier graag verwijzen, heeft gepleit voor een Wet inzake Europese subsidies.93 De achterliggende gedachte is dat op die manier kan worden aangesloten bij Awb-bepalingen waar dat zonder problemen kan, zodat eenheid zoveel mogelijk wordt gewaarborgd, maar tegelijkertijd kan worden voorkomen dat Awbbepalingen omwille van Europeesrechtelijke verplichtingen zodanig dienen te worden 'opgerekt' dat zij feitelijk een andere betekenis krijgen, met alle rechtsonzekerheid van dien.

Het staatssteunrecht heeft de afgelopen 15 jaar tot vergelijkbare problemen gezorgd. In artikel 8 Kaderwet financiële verstrekkingen EZ was destijds al een uitdrukkelijke intrekkingsgrond opgenomen voor het geval dat een verstrekte subsidie aan een onderneming onrechtmatige staatssteun bleek te vormen. De Awb-wetgever vond het niet voor de hand liggen dat ook in de subsidietitel te regelen. Dat zou niet goed mogelijk zijn, omdat iedere subsidieverstrekking weer anders is en niet steeds steunverlening inhoudt, en ook niet nodig zijn, omdat bestuursorganen wanneer nodig zich rechtstreeks op het staatssteunrecht zouden kunnen beroepen. ${ }^{\mathbf{9 4}}$ Ook deze gedachte bleek te optimistisch. Verschillende problemen deden zich voor die wij hier niet allemaal kunnen bespreken.95 Een belangrijk knelpunt deed zich gevoelen bij de vraag of staatssteun verstrekt in de vorm van subsidies ook bij andere partijen dan de subsidieontvanger door verstrekkende bestuursorganen mochten worden teruggevorderd als zij de uiteindelijke begunstigden bleken te zijn. Dat was bijvoorbeeld het geval bij de oliemaatschappijen die door private contracten de voordelen voelden van de eerder genoemde 'subsidies' verstrekt aan pomphouders in de grensstreek. ${ }^{\mathbf{9 6}}$ Ook de vraag of rente mocht worden geheven over de teruggevorderde subsidiegelden over de periode dat deze (onrechtmatig) bij de ontvanger hebben verbleven, was lastig. Op grond van het 
staatssteunrecht is vereist dat de onrechtmatige steun inclusief (een op Europees niveau vastgelegde) rente wordt teruggevorderd bij de begunstigde om zo de marktsituatie te herstellen. Het is echter vaste Nederlandse jurisprudentie dat een rentevordering per besluit dient te berusten op een expliciete wettelijke grondslag en die biedt de subsidietitel niet.97 Die twee verschillende uitgangspunten kwamen tot een pijnlijke botsing in de zogenaamde BPM zaak, waarin de Europese Commissie de terugvordering had gelast van subsidies verstrekt aan producenten van kunstmest, waarna de Afdeling bestuursrechtspraak vaststelde dat een rentevordering op grond van het publiekrecht in dit geval niet mogelijk was. ${ }^{\mathbf{9 8}}$ Dat leidde zelfs tot een infractieprocedure tegen Nederland, met als grondslag het verwijt dat het in Nederland niet goed mogelijk zou zijn het staatssteunrecht effectief ten uitvoer te leggen.

Deze gebeurtenissen leidden uiteindelijk tot het Wetsvoorstel terugvordering staatssteun, waarin belangrijke wijzigingen in de Awb worden voorgesteld. 99 Dit wetsvoorstel ligt al sinds 2008 ter behandeling in de Tweede Kamer. Dat lijkt er opnieuw op te wijzen dat de Europese aspecten van het (subsidie)recht niet tot de prioriteiten van de Awb-wetgever behoren.

\section{Uitvoeringslasten en Uniform Subsidiekader}

Hoewel de inwerkingtreding van de subsidietitel tot gevolg had dat allerlei juridische aspecten van de subsidieverhouding voortaan op een - min of meer uniforme wijze geregeld waren, bleven er op het gebied van de uitvoering van subsidieregelingen (belangrijke) verschillen bestaan tussen bestuursorganen. Deze verschillen leidden niet alleen tot vaak hoge uitvoeringslasten voor de overheid, ${ }^{\mathbf{1 0 0}}$ maar ook tot (soms onnodige) administratieve lasten voor justitiabelen. Zo moest het Leger des Heils, een landelijk werkende instelling die met verschillende subsidieverstrekkende overheden te maken heeft, wel 25 jaarrekeningen laten opstellen vanwege de verschillende eisen van de verschillende subsidieverstrekkers. ${ }^{101}$ In 2007 besloot het toenmalige kabinet dat de rijksoverheid kleiner en efficiënter moest worden en dat dat onder meer zou kunnen worden bereikt door de uniformering en vereenvoudiging van de uitvoering van het subsidiebeleid, opdat de uitvoerings- en administratieve lasten zouden verminderen. ${ }^{\mathbf{1 0 2}}$ Dit voornemen heeft geresulteerd in twee "producten": het zgn. uniform subsidiekader, een beleidstuk waarin maatregelen voor een eenvoudiger beheer en uitvoering van subsidies werden beschreven en een regeling van de Minister-President waarin bepaalde onderdelen van het uniform subsidiekader zijn uitgewerkt. ${ }^{\mathbf{1 0 3}}$ Deze "Aanwijzingen voor subsidieverstrekking” hebben een status die het best te vergelijken is met die van de Aanwijzingen voor de regelgeving; zoals opstellers van wet- en regelgeving rekening moeten houden met de Aanwijzingen voor de regelgeving, zo moeten opstellers van subsidieregelingen rekening houden met de Aanwijzingen voor subsidieverstrekking. ${ }^{\mathbf{1 0 4}}$

Hoe moet die vermindering van uitvoeringslasten en administratieve lasten volgens de Aanwijzingen worden bereikt? Kort gezegd, bevatten de Aanwijzingen daarvoor drie soorten maatregelen. Ten eerste moeten subsidies worden ingedeeld in kleine, middelgrote en grote subsidies. ${ }^{\mathbf{1 0 5}}$ Aan de ontvangers van kleinere subsidies mogen op het gebied van de verantwoording minder eisen worden gesteld dan aan de ontvangers van middelgrote subsidies en aan de ontvangers van middelgrote subsidies mogen op hun beurt minder eisen worden gesteld dan aan de ontvangers van grote subsidies. Een tweede maatregel die moet bijdragen aan de beoogde lastenreductie is de uniformering en de 
vereenvoudiging van begrippen, termijnen, bevoorschottingsregels en de berekeningswijze van uurtarieven. De derde categorie van maatregelen heeft betrekking op het tegengaan van subsidiemisbruik. Zo moet bij het opstellen van een subsidieregeling een risicoanalyse worden uitgevoerd (en vastgelegd) en moet het bestuursorgaan geconstateerd misbruik van de subsidieregeling registreren. ${ }^{\mathbf{1 0 6}}$ Bij deze derde categorie maatregelen valt op dat het kader alleen betrekking heeft op herstelsancties. Er is dus (nog) geen relatie met de hiervoor al genoemde Wet bestuurlijke boete meldingsplichten door ministers verstrekte subsidies.

De werking van de Aanwijzingen wordt gemonitord door de Minister van Financiën (in samenwerking met de betrokken ministeries). Zeer onlangs is er een eerste evaluatie van de Aanwijzingen naar de Tweede Kamer gestuurd. ${ }^{\mathbf{1 0}} 7$ Uit die rapportage komt naar voren dat alle departementale subsidieregelingen inmiddels zijn aangepast en dat de meeste subsidies volgens het USK worden verstrekt. Het gedeelte van de rapportage over de ervaringen met het uniforme subsidiekader en de Aanwijzingen voor subsidieverstrekking, heeft betrekking op de ervaringen van de ministeries. Deze ervaringen zijn overwegend positief. Wat de ervaringen van subsidieontvangers zijn, kan niet uit de rapportage worden afgeleid. Volgens de opstellers van de rapportage was het nog te vroeg om dit te onderzoeken. Ministeries zijn zich wel bewuster geworden van de noodzaak van risicobeheersing, maar de risico-analyse wordt nog te weinig expliciet vastgelegd. Voor wat betreft de vraag hoe het sanctie-instrumentarium werkt, vermeldt de rapportage dat "de sancties in het USK door de departementen worden toegepast en dat departementen ernstige onregelmatigheden registreren" ${ }^{108}$ Zoals gezegd bevat het uniforme subsidiekader zelf geen (nieuwe) sanctie-instrumenten. Het begrip sanctie moet in dit verband dus beperkt worden uitgelegd; bij subsidies worden in beginsel ${ }^{\mathbf{1 0 9}}$ alleen herstelsancties opgelegd. ${ }^{\mathbf{1 1 0}}$ In het uniforme subsidiekader is "slechts" ingegaan op de wettelijke mogelijkheden die er al waren om toezicht te houden en zo nodig handhavend op te treden. Daarnaast is er beleid geformuleerd over het inzetten van die mogelijkheden, zodat bestuursorganen zoveel mogelijk hetzelfde handelen bij het toezicht houden en handhaven. Zo is bijvoorbeeld uiteengezet dat het de bedoeling is dat niet meer bij alle subsidieontvangers wordt gecontroleerd of ze zich aan de subsidieverplichtingen houden, maar dat er steekproeven worden gehouden.

Deze paragraaf laat zien dat de harmonisatie van subsidieregels die heeft plaatsgevonden in de subsidietitel, jaren later een vervolg gekregen in een (beperkte, maar zeker niet onbelangrijke) harmonisatie van beleid. Het accent ligt daarbij op vermindering van administratieve lasten en op handhaving. Interessant is de vraag of dat verschijnsel, harmonisering van beleid, zich vaker voordoet als gevolg van of ten minste volgend op Awb-wetgeving.

\section{Horizonbepaling en evaluatie van subsidieregelingen}

De Aanwijzingen voor subsidieverstrekking zijn per 1 juli 2012 aangevuld met een artikel waarin opstellers van subsidieregelingen wordt bevolen om in subsidieregelingen steeds een horizonbepaling op te nemen. De Tweede Kamer dringt er al jaren op aan dat subsidieregelingen voortaan standaard worden voorzien van een einddatum. ${ }^{\mathbf{1 1 1}}$ De reden hiervoor is dat "een periodieke heroverweging van nut en noodzaak van subsidieregelingen past (...) in het huidige tijdsgewricht. Een wettelijke horizonbepaling vergroot, zoals de Kamer dat wenst, de betrokkenheid van de Kamer bij de instelling en voortzetting van een subsidieregeling, en dus bij een periodieke heroverweging daarvan."112 
Het is de bedoeling dat deze horizonbepaling uiteindelijk in de

Comptabiliteitswet wordt opgenomen. Deze wet wordt thans gemoderniseerd en herzien en omdat inwerkingtreding ervan daardoor nog wel even op zich kan laten wachten, maar ook omdat het kabinet snel tegemoet wilde komen aan deze wens van de Tweede Kamer, is besloten om de horizonbepaling alvast, tijdelijk in de Aanwijzingen voor subsidieverstrekking op te nemen. Daarin is nu geregeld dat in subsidieregelingen een tijdstip moet staan waarop die regeling vervalt. Dat tijdstip mag maximaal vijf jaar na de datum van inwerkingtreding liggen. ${ }^{\mathbf{1 1 3}}$ Onder een subsidieregeling wordt in dit verband verstaan "een algemene maatregel van bestuur of een ministeriële regeling op grond waarvan een concrete subsidieverlening kan plaatsvinden" (Aanwijzing 6A, eerste lid). Dit betekent dus dat subsidiewetten (zoals de kaderwetten) niet van een horizonbepaling hoeven te worden voorzien.

Als het de bedoeling is dat de te vervallen regeling wordt voortgezet, of, wanneer nadat de regeling is vervallen, nagenoeg dezelfde activiteiten opnieuw worden gesubsidieerd (op grond van een nieuwe regeling die inhoudelijk nauwelijks afwijkt van de vorige), dan wordt een - van een motivering voorzien - ontwerp van de nieuwe regeling voorgehangen bij de Tweede Kamer. De Kamer krijgt daarna vier weken de gelegenheid op opmerkingen te maken en met de betrokken bewindspersoon van gedachten te wisselen.

Hoe de regeling er precies uit komt te zien als zij straks in de herziene Comptabiliteitswet wordt opgenomen, valt nog niet te voorzien. Het wordt in ieder geval interessant om te volgen hoe dit voorschrift in de praktijk gaat uitwerken. Vooropgesteld zij dat ook wij menen dat het goed is om van tijd tot tijd te bezien of een subsidieregeling nog nodig is. Het doel van de subsidieregeling kan inmiddels immers zijn bereikt. Ook kan in de loop der tijd duidelijk worden dat het doel van de subsidie niet is bereikt en ook niet zal worden bereikt of dat er ongewenste neveneffecten zijn opgetreden. Stoppen met subsidiëren ligt dan voor de hand. Deze redenering lag ook ten grondslag aan de beslissing van de wetgever om in de subsidietitel te bepalen dat subsidieregelingen periodiek moesten worden geëvalueerd (artikel 4:24 Awb). ${ }^{114}$ Opvallend is wel dat bij de voorbereiding van de subsidietitel expliciet is ingegaan op de keuze tussen een evaluatiebepaling en een horizonbepaling. In de toelichting op Aanwijzing 6A wordt aan deze kwestie echter geen woord vuil maakt. Daardoor is de verhouding van een horizonbepaling tot de evaluatieplicht onduidelijk.

Het lijkt ons raadzaam dat bij de voorbereiding van de horizonbepaling voor subsidies in de Comptabiliteitswet rekening wordt gehouden met het feit dat subsidies niet alleen worden verstrekt voor kortlopende projecten, maar ook voor uit maatschappelijk oogpunt essentiële voorzieningen, waarvan bij voorbaat vaststaat dat zij voor lange of onbepaalde tijd moeten worden gehandhaafd, zoals jeugdhulpverlening en onderwijs. In de memorie van toelichting bij artikel 4:24 Awb is destijds uitdrukkelijk aandacht gevraagd voor dergelijke subsidies. Aangezien er nog steeds subsidies worden verstrekt voor "uit maatschappelijk oogpunt essentiële voorzieningen" is er alle reden hier rekening mee te houden en niet rigoureus voor alle subsidies een horizonbepaling in te voeren. ${ }^{\mathbf{1 1 5}}$ Verder moet bij het vervallen van regelingen goed worden nagedacht over de verhouding tot het bepaalde in artikel 4:51 Awb, waarin langdurige subsidierelaties juist worden beschermd.

Hoewel het veelvuldig tot stand brengen van verlengingswetten, ook wanneer de noodzaak van voortzetting van de subsidiëring niet ter discussie staat, een ondoelmatige inzet van wetgevingscapaciteit oplevert, ${ }^{\mathbf{1 1 6}}$ biedt de subsidietitel hiervoor een "uitweg": een optie die geen wetgevingscapaciteit vergt en die dus 
zomaar heel aantrekkelijk zou kunnen blijken in de praktijk. Bestuursorganen zouden vaker hun toevlucht kunnen nemen tot de mogelijkheid om de subsidie in de vorm van een begrotingssubsidie te verlenen. Op grond van artikel 4:23 Awb is er dan immers geen wettelijke grondslag vereist. De enige eisen zijn dat de naam van de ontvanger en het subsidiebedrag op de begroting van het bestuursorgaan of de toelichting daarop worden opgenomen, zodat democratische controle mogelijk blijft. Wij zouden dit geen goede ontwikkeling vinden; het zou een stap terug zijn in de richting van het ongeregelde en ondoorzichtige subsidiebeleid van voor titel 4.2 Awb.

Subsidieverlenende bestuursorganen die dergelijke van een vervaltermijn voorziene subsidieregelingen uitvoeren, hebben er ook een paar praktische klusjes bij gekregen. Zo zal men moeten organiseren dat er op tijd "een belletje gaat rinkelen". Alleen dan kan er tijdig worden nagedacht over de vraag of de subsidieregeling moet worden voortgezet. Als het antwoord op die vraag bevestigend is, volgt de praktische gang van zaken: het verlengingsvoorstel voorbereiden en in procedure brengen en dat alles tijdig voor de vervaldatum. ${ }^{\mathbf{1 1 7}}$ Het lijkt ons dat het laatste woord over dit onderwerp nog niet is gesproken. In ieder geval is de vraag gerechtvaardigd hoe de voordelen van een vervaltermijn zich verhouden tot de daarmee gepaard gaande administratieve lasten. ${ }^{\mathbf{1 1 8}}$

\section{Slotbeschouwing}

Aan het begin van dit artikel gaven wij aan te willen nagaan welke onderwerpen en vraagstukken op het terrein van het subsidierecht vijftien jaar geleden belangrijk waren, welke de afgelopen vijftien jaren belangrijk zijn geworden en welke naar ons idee in de nabije toekomst belangrijk zullen worden of blijven. Zonder de eerdere bevindingen uitgebreid te herhalen, kunnen we aan het eind van dit artikel constateren dat er de afgelopen 15 jaar veel is gebeurd op subsidiegebied. Sommige onderwerpen waarvan de wetgever voor 1998 dacht dat ze belangrijk waren, hebben na de inwerkingtreding van de subsidietitel nauwelijks aandacht meer gekregen, althans in de jurisprudentie (zoals de wettelijke grondslag en de uitvoeringsovereenkomst van art. 4:36 Awb), terwijl andere aanleiding bleven geven tot discussie (zoals de wenselijkheid van uitzonderingen in bijzondere wetgeving, verdeelsystematiek en het tegengaan van misbruik en oneigenlijk gebruik van subsidieregelingen). Wij denken dat de inwerkingtreding van de subsidietitel per 1 januari 1998 ertoe heeft geleid dat er in de chaos van het subsidierecht op belangrijke punten orde is geschapen. De wetgever heeft - meer dan in Awb-regelingen over andere onderwerpen daadkrachtig geordend, keuzes gemaakt en knopen doorgehakt. Maar uit deze bijdrage wordt ook duidelijk dat het voor de wetgever niet altijd eenvoudig is te voorzien welke onderwerpen van algemeen bestuursrecht voor de rechtspraktijk belangrijk zullen blijken te zijn, hoe de werking van sommige bepalingen in de praktijk uitpakt en of er behoefte zal bestaan aan nadere regels of regels over andere onderwerpen.

Uit de eerste evaluatie van de subsidietitel in 2001 bleek al dat de invoering van de subsidietitel, ondanks de omvang en complexiteit ervan, zonder noemenswaardige problemen is verlopen. ${ }^{\mathbf{1 1 9}}$ Wel bleek uit diezelfde evaluatie dat de praktijk het subsidierecht ingewikkelder vond geworden. Dat kwam met name door het gelaagde karakter van de regelgeving: de Awb heeft zelf al een gelaagde structuur en daarbij kwam dan ook nog eens de gelaagdheid van de subsidietitel, in combinatie met bijzondere subsidieregelgeving. De bijzondere regelgeving bestaat vervolgens vaak ook nog uit verschillende niveaus en ook in de subsidiebeschikking zelf vindt men vaak nog bepalingen die de rechtspositie 
van subsidieontvangers bepalen. Dit gelaagde systeem, afgezet tegen de situatie vroeger waarin alle voor een subsidierelatie relevante regels in één wettelijke regeling te vinden waren, vraagt inderdaad meer van mensen die niet dagelijks met subsidierecht te maken hebben (waarvan er naar onze indruk velen zijn in de uitvoeringspraktijk). Hier staat echter tegenover dat onder andere de harmonisatie van de begrippen, de algemene verstrekkingsystematiek, de codificatie van intrekkings- en wijzigingsgronden en de schadevergoedingsbepalingen van artikel 4:50 en 4:51 Awb, voor rechtstoepassers zoals bestuursorganen, rechtshulpverleners, rechters, wetenschappers en de (lagere) wetgever ook belangrijke voordelen heeft opgeleverd. De algemene regels zorgen ervoor dat het subsidierecht als geheel een rechtsgebied is geworden dat in samenhang kan worden bestudeerd. Daarvan wordt geprofiteerd bij maken van nieuwe subsidieregelingen en het behandelen van subsidiegeschillen. ${ }^{\mathbf{1 2 0}}$ Dit komt uiteindelijk de rechtsgelijkheid en rechtszekerheid ten goede.

Een opvallende ontwikkeling die wij in dit kader ook willen signaleren is dat de juridische harmonisatie die in titel 4.2 vorm heeft gekregen, de afgelopen jaren is gevolgd door harmonisatie van subsidiebeleid op rijksniveau. Daarbij gaat het om algemene onderwerpen van het subsidiebeleid. Afgesproken is bijvoorbeeld dat in rijkssubsidieregelgeving voortaan dezelfde beslistermijnen worden gebruikt, dat uniforme begrippen worden gehanteerd en dat misbruik en oneigenlijk gebruik van subsidies op een uniforme wijze worden aangepakt. Naar onze mening is de totstandkoming van titel 4.2 een belangrijke factor geweest voor deze ontwikkeling. Door de subsidietitel en de op grond daarvan tot stand gebrachte bijzondere subsidieregelgeving kon veel beter dan voorheen aan het licht komen dat de verschillende bestuursorganen op rijksniveau bij de totstandkoming van subsidieregelgeving en -beleid in veel gevallen voor dezelfde vraagstukken een oplossing moeten vinden. Dat men is overgegaan tot bundeling van de krachten verbaast ons dan ook niet. Ook op decentraal niveau is een dergelijke ontwikkeling waar te nemen. ${ }^{\mathbf{1 2 1}}$

Ondanks het feit dat de systematisering en harmonisering waarin titel 4.2 heeft voorzien, belangrijke voordelen biedt, hebben we in deze bijdrage ook laten zien dat de neiging tot het maken van uitzonderingen in de praktijk groot is. Dit geldt niet alleen voor bijzondere wetgever, maar ook voor de Awb-wetgever zelf. De uitzonderingen die in 1998 voor fiscale en onderwijssubsidies zijn gemaakt, illustreren dit verschijnsel. Ook wordt er in de bijzondere wetgeving vrolijk afgeweken en worden er aanvullende wetten gemaakt over het subsidierecht die om onduidelijke reden, weer geen plaats krijgen in de Awb. Dit valt waarschijnlijk niet te voorkomen; ten slotte is de Awb ook maar een 'gewone' formele wet.

Of het gesystematiseerde en geharmoniseerde subsidierecht heeft geleid tot een doelmatiger subsidiebeleid dat minder geld kost (dit waren ten tijde van de voorbereiding en inwerkingtreding van titel 4.2 ten slotte ook belangrijke doelstellingen), wagen wij te betwijfelen. De Algemene Rekenkamer heeft erop gewezen dat subsidieregelingen veelal niet worden geëvalueerd. Als ze wel zijn onderworpen aan een evaluatie, dan is er in de meeste gevallen niet naar effectiviteit gekeken. Besteedt de evaluatie daaraan wel aandacht, dan gebeurt dat zelden op een deugdelijke manier; de evaluaties maken doorgaans niet duidelijk of de subsidies effectief zijn of niet. ${ }^{\mathbf{1 2 2}}$ Een ander aspect betreft de kosten die gemoeid zijn met subsidieverstrekking. In het Financieel jaarverslag van het Rijk 2006 kondigde de Minister van Financiën aan de uitvoeringslasten voor subsidieverstrekkers en de administratieve lasten voor subsidieontvangers te willen reduceren. Deze lasten waren, zo schreef hij, hoog en bedroegen soms 
wel 20\% van het beschikbare subsidiebedrag. ${ }^{\mathbf{1 2 3}}$ Ter uitvoering van dit voornemen hebben verschillende stukken het licht gezien, bijv. de Nota "Kader financieel beheer Rijkssubsidies" (USK), de Aanwijzingen voor subsidieverstrekking en de beleidsnota Raamwerk voor uitvoering van subsidies. Over de concrete resultaten in termen van vermindering van kosten is, voor zover wij weten, nog niets bekend.

Voorts is beslist opvallend dat de wetgever Europese aspecten tot nu toe niet graag lijkt te verwerken in de algemene regels van bestuursrecht, althans niet in de subsidietitel. Ook nadat problemen waren gebleken, zowel op het gebied van staatssteun als op het gebied van het verstrekken van Europese subsidies door Nederlandse bestuursorganen, wordt er niet hard getrokken aan wetgeving die die problemen moet oplossen. Dat leidt er in sommige gevallen toe dat de bestuursrechter bepalingen van de Awb zodanig moet 'oprekken' om Europeesrechtelijke verplichtingen te voldoen, dat weinig recht meer wordt gedaan aan de bedoeling die de Awb-wetgever had met die bepalingen.

Tot slot kunnen we constateren dat de subsidietitel over een aantal meer algemene bestuursrechtelijke onderwerpen al een (specifieke op subsidierelaties toegesneden) regeling bevat die op termijn een basis zou kunnen vormen voor meer algemene codificatie. Gedacht kan worden aan een regeling van het vertrouwensbeginsel of over de intrekking en wijziging van beschikkingen. $\mathrm{Al}$ in het voorontwerp voor de eerste tranche Awb schreef de Commissie Warb dat het wenselijk was het laatstgenoemde onderwerp in de Awb te regelen. ${ }^{\mathbf{1 2 4}}$ Tot nu toe is het daar echter niet van gekomen. Toch zagen wij in paragraaf 8 van deze bijdrage dat de bestuursrechter inmiddels bereid is bijvoorbeeld artikel 4:51 Awb (inzake het vertrouwensbeginsel) breder toe te passen. Die jurisprudentie illustreert harmoniserende activiteiten van de bestuursrechter over de band van Awb-bepalingen.

De systematisering en harmonisering van subsidierecht heeft naar onze mening dus veel positieve effecten gehad. Aan de daarop gevolgde harmonisatie van beleid zien we voorlopig nog geen einde komen en dat lijkt ons een goede, want efficiënte ontwikkeling. Op het vlak van onderzoek naar de effecten van subsidies moet naar onze mening wel veel meer gebeuren. Om verstandige beslissingen te kunnen nemen, zeker in deze financieel zware tijd, is het noodzakelijk te weten of en hoe subsidieregelingen werken. Ook de wetgever moet aan de slag: problemen met het Europese recht moeten worden opgelost en de onderwerpen die inmiddels voor codificatie in aanmerking komen kunnen ter hand worden genomen. Aparte (algemene) subsidiewetten die tot stand zijn gekomen moeten worden beoordeeld op hun geschiktheid voor opname in de Awb, het is niet genoeg dat harmonisatie 15 jaar gelden met de inwerkingtreding van titel 4.2 Awb is bewerkstelligd. De op die wijze bereikte eenheid van subsidierecht dient ook te worden bewaakt en bewaard, zodat het subsidierecht over 15 jaar nog steeds coherent en hopelijk nog efficiënter is.

\section{Noten}

1 De parlementaire enquête inzake het RSV-concern (Kamerstukken II 1984/85, 17 817, nrs. 16-21) en de parlementaire enquête inzake de subsidiering van de volkshuisvesting (Kamerstukken II 1987/88, 19 623).

2 Zie de rapportage 'geïntegreerd subsidiebeleid', Kamerstukken II 1991/92, 22 150, nr. 5 .

3 Bijv. C.A.J.M. Kortmann, 'Wie van de drie: de algemene wet, de algemene wet 
of de bijzondere wet?', in: C.A.J.M. Kortmann, B.P. Vermeulen, P.J.J. Zoontjens, 'De Awb en de bijzondere wetgeving, VAR-preadviezen 20oo', VAR-reeks 124, Den Haag: Boom Juridische uitgevers 2000.

4 Parlementaire Geschiedenis Awb III, p. 162.

5 Wie als zoekterm het woord 'subsidie' gebruikt in rechtspraak.nl op het rechtsgebied 'bestuursrecht', als selectie-instrument gebruikt dat de zoekterm voor moet komen in de inhoudsindicatie van de uitspraak en de selectie laat lopen vanaf 1 januari 1998, verkreeg op 11 oktober 2013 een dataset van 1243 uitspraken.

6 Wij kozen voor: I.C. van der Vlies, 'Subsidie', NJB 1998, p. 767 e.v., C.M. Bitter en E.J. Daalder, 'Codificatie van subsidieregels; de gevolgen voor de huidige praktijk', Stichting \& Vereniging 1995, p. 95 e.v., J. Veltman, 'Subsidiering volgens de Algemene wet bestuursrecht', de Gemeentestem 1995, p. 125 e.v. (deel I) en p. 166 e.v. (deel II), en ten slotte, van eigen hand, M.J. Jacobs en W. den Ouden, 'Hoedt u voor artikel 4:36 Awb, problemen rond het gebruik van uitvoeringsovereenkomsten bij subsidieverstrekking', NTB 1997, p. 254 e.v., waarbij zij aangetekend dat voor die laatste bijdrage geldt dat destijds vooral het tijdschrift waarin werd gepubliceerd toonaangevend was (en dus niet de auteurs ).

7 W. Den Ouden, M.J. Jacobs \& N. Verheij, 'Subsidierecht', Deventer: Kluwer 2011.

8 Parlementaire Geschiedenis Awb I, p. 19.

9 Kamerstukken II 1993/94, 23 700, nr. 3, p. 18 e.v.

10 Kamerstukken II 1993/94, 23 700, A, p. 23 (punt. 6.3).

11 Kamerstukken II 1993/94, 23 700, A, p. 24.

12 Kamerstukken II 1993/94, 23 700, nr. 3, p. 21.

13 Kamerstukken II 1993/94, 23 700, nr. 3, p. 30.

14 Vgl. ABRvS 8 oktober 2008, ECLI:NL:RVS:2008:BF7186, AB 2009, 223, m.nt. W. den Ouden.

15 Zie bijvoorbeeld ABRvS 22 februari 2006, ECLI:NL:RVS:2006:AV2276, AB 2006, 214, m.nt. I.C. van der Vlies (Stichting Six), ABRvS 8 oktober 2008, ECLI:NL:RVS:2008:BF7186, AB 2009, 223, m.nt. W. den Ouden (Gondelproject Delft) en CBb 9 juli 2008, ECLI:NL:CBB:2008:BD8180, AB 2008, 340, m.nt. J.R. van Angeren (Hanseland).

16 Zie over de Stichting koppeling ABRvS 11 oktober 2006, ECLI:NL:RVS:2006:AY9897, AB 2007, 81, m.nt. I. Sewandono, JB 2006, 321, m.nt. H. Peters, ABRvS 18 juni 2008, ECLI:NL:RVS:2008:BD5087, AB 2008, 235, m.nt. T. Barkhuysen en W. den Ouden, JB 2008, 177.

17 Daarover Den Ouden, Jacobs \& Verheij 2011, p. 11 e.v. 
18 Zie onder meer HvJ EG 13 juni 2002, zaak C-382/99, AB 2002, 248, m.nt. F.H. van der Burg (steun aan pomphouders grensstreek) en ABRvS 22 juni 2005, ECLI:NL:RVS:2005:AT8010, AB 2005, 441, m.nt. W. den Ouden en M.K.G. Tjepkema (subsidieregeling opkoop pluimvee). Zie over deze jurisprudentie verder: W. den Ouden en M.K.G. Tjepkema, 'Voor hetzelfde geld. Over de kwalificatie van publiekrechtelijke financiële verstrekkingen en hun wettelijk kader', NTB 2006, p. 101 e.v.

19 Zie daarover N. Verheij, 'Fiscale Eigenwijsheden', NTB 2013, 6, die zelfs spreekt van fiscaal separatisme.

20 Zie bijv. ABRvS 11 december 2013, ECLI:NL:RVS:2013:2323.

21 De WBSO is een verzamelnaam voor de afdrachtvermindering voor speur en ontwikkelingswerk in de Wet vermindering afdracht loonbelastingen en premie voor de volksverzekeringen (WVA) en de aftrek speur- en ontwikkelingswerk in de Wet IB 2001. De WBSO-regeling heeft alle kenmerken van een subsidieregeling. Er wordt namelijk een aanspraak op een financieel voordeel verstrekt aan de belastingplichtige met het oog op innovatieactiviteiten door een bestuursorgaan.

22 Wie over een S\&O-verklaring in het kader van de WSBO-regeling beschikt kan ook in aanmerking komen voor een zogenaamde RDA-beschikking. In artikel 3.52a Wet IB is een aanvullende aftrekmogelijkheid voor speur- en ontwikkelingswerk neergelegd.

23 Artikel 12b Wet Vpb.

24 Zie o.a. Van der Vlies 1998, p. 768 en Veltman 1995, p. 128.

25 Zie eerst ABRvS 14 februari 2007, ECLI:NL:RVS:2007:AZ8495 (ROC Zadkine), waarin titel 4.2 Awb simpelweg wordt toegepast in geschil over een terugvordering van bekostigingsgelden en ABRvS 14 februari 2007, ECLI:NL:RVS:2007:AZ8496 (ROC West-Brabant), waarin dat ook gebeurt, maar e.e.a. uitgebreid wordt toegelicht.

26 Zie bijv. ABRvS 10 oktober 2012, ECLI:NL:RVS:2012:BX9681, AB 2013, 162, m.nt. W. den Ouden.

27 Het Ministerie van Financiën brengt elke vier jaar een subsidieoverzicht van het Rijk uit.

28 SOR 2010, Kamerstukken II 2009/10, 32 335, nr. 1, bijlage 1. Helemaal consequent is het SOR 2010 echter niet, want er worden toch ook enkele verstrekkingen als subsidie aangemerkt die niet onder de Awb-definitie vallen. Het gaat bijvoorbeeld om de bijdrage aan het Internationaal Strafhof (zie onder Ministerie van Buitenlandse Zaken, nr. 298).

29 De cijfers uit het SOR 2003 komen uit het eindrapport "Zicht op subsidies" die de Minister van Financiën op 7 maart 2003 aanbood aan de voorzitter van de Tweede Kamer (Kamerstukken II 2002/o3, 28 600, nr. 65), Instrumentenoverzicht Rijk, Kamerstukken II, 2005/o5, 30300 IXB, nr. 27 (overigens wordt uit het Instrumentenoverzicht Rijk niet duidelijk wat precies 
onder overdrachten moet worden verstaan, zodat niet met zekerheid is te zeggen wat het totaalbedrag aan subsidies was).

30 Zie 'Handleiding Europees systeem van nationale en regionale rekeningen 1995 (ESR 1995)', p. 17.

31 J.A. de Boer, F.C.M.A. Michiels, W. den Ouden \& P.J.J. Zoontjens, 'Anders, of toch niet? Een onderzoek naar de mogelijkheden van meer Awb-conforme onderwijswetgeving (2013)', n.n.g.

32 Zie bijv. L.J.A. Damen, 'Ongeregeld en ondoorzichtig bestuur (diss. Groningen)', Deventer: Kluwer 1987, p. 807 e.v. en E.M.H. Hirsch Ballin, 'Rechtsstaat, grondrechten en subsidieverhoudingen, VAR-geschrift XCIX', Alphen a/d Rijn: Samsom H.D. Tjeenk Willink 1988, p. 63 e.v.

33 Zie bijv. de discussie naar aanleiding van de VAR-preadviezen van Van Kreveld en Hirsch-Ballin in 1988 (VAR-geschrift 101, p. 20, 23 en 73), maar ook F.J. van Ommeren, 'De verplichting verankerd, De reikwijdte van het legaliteitsbeginsel en het materiële wetsbegrip', Deventer: Kluwer 1996, p. 378 en W. den Ouden, 'De subsidieverplichting: wie betaalt, bepaalt? Een onderzoek naar de rechtmatigheid van subsidieverplichtingen', Deventer: Kluwer 2002.

34 Zie de in noot 7 genoemde artikelen en ook M.J. Jacobs, 'Subsidieovereenkomsten. Een onderzoek naar de rechtsvormen van subsidies, in het bijzonder overeenkomsten', Den Haag: Elsevier 1999, paragraaf 3.5.2.

35 ABRvS 9 april 2008, ECLI:NL:RVS:2008:BC9067, AB 2008, 166, m.nt. R. Ortlep (busstation Middelburg).

36 ABRvS 12 maart 2008, ECLI:NL:RVS:2008:BC6426,JB 2008, 106, m.nt. E. Hardy.

37 ABRvS 20 oktober 2004, ECLI:NL:RVS:2004:AR4298, JB 2004, 389, m.nt. A.J. Blok, AB 2005, 157, m.nt. N. Verheij (Stichting Fonds MKZ), ABRvS 14 mei 2008, ECLI:NL:RVS:2008:BD1474, JB 2008, 141 (Kinderopvang Enschede), CRvB 2 oktober 2007, ECLI:NL:CRVB:2007:BB5939, AB 2008, 192, m.nt. J.E. van den Brink (Werkzoekendensubsidie Almere).

38 EHRM 18 mei 2010, AB 2010, 189, m.nt. T. Barkhuysen en W. den Ouden.

39 CRvB 2 oktober 2007, ECLI:NL:CRVB:2007:BB5939, AB 2008, 192, m.nt. J.E. van den Brink.

40 Zie ook: Den Ouden, Jacobs \& Verheij 2011, p. 233.

41 J.H. Jans, R. De Lange, S. Prechal, R.J.G.M. Widdershoven, 'Inleiding tot het Europees bestuursrecht', Nijmegen: AAe-Libri 2011, p. 21, Den Ouden, Jacobs \& Verheij 2011, p. 37 en 234, J.E. van den Brink, 'De uitvoering van Europese subsidieregelingen in Nederland. Juridische knelpunten en uitdagingen (diss. Leiden)', Deventer: Kluwer 2012, p. 551-558.

42 ABRvS 19 april 2006, ECLI:NL:RVS:2006:AW2275, AB 2006, 296, m.nt. 
M.J. Jacobs en W. den Ouden, JB 2006, 155 (Flevoherb I), CBb 22 december 2009, ECLI:NL:CBB:2009:BL0650, AB 2010, 74, m.nt. R. Ortlep, CBb 22 december 2009, ECLI:NL:CBB:2009:BL0649.

43 HvJ 13 maart 2008, AB 2008, 207, m.nt. W. den Ouden (ESF-arrest), HvJ 21 december 2011, zaak C-465/10, AB 2013, 86, m.nt. J.E. van den Brink (Chambre de Commerce Indre), HvJ 13 december 2012, zaak C-670/11 (Vinifrance) en HvJ 20 juni 2013, zaak C-568/11 (Agroferm).

44 Kamerstukken II 1993/94, 23 700, nr. 3, p. 42.

45 M.J. Jacobs, 'De tenuitvoerlegging van Europese structuurfondsen in Nederland: over het verstrekken van EG-subsidies en het beheersen van de uitgaven', in: T. Barkhuysen, W. den Ouden en E. Steyger (red.), 'Europees recht effectueren', Alphen a/d Rijn: Kluwer 2007, p. 185, Den Ouden, Jacobs \& N. Verheij 2011, p. 38, Van den Brink 2012, p. 572.

46 Vgl. ARBvS 3 januari 2007, ECLI:NL:RVS:2007:AZ5491, AB 2007, 224, m.nt. W. den Ouden en JB 2007, 31, m.nt. AJB (ESF-subsidieplafond) en CBb 16 maart 2006, ECLI:NL:CBB:2006:AV7337, AB 2007, 22, m.nt. H. Griffioen en W. den Ouden (Stichting ROM).

47 Zie noot 42.

48 Zie hierover uitgebreid Den Ouden, Jacobs \& N. Verheij 2011, hoofdstuk 8. Wij focussen hier op de verdeelsystematiek. Daarover is de meeste jurisprudentie gekomen de afgelopen 15 jaar. Over het instellen van een subsidieplafond en het rechtskarakter van een subsidieplafond is veel minder jurisprudentie gewezen.

49 Van der Vlies 1998, p. 767.

50 Parlementaire Geschiedenis Awb III, p. 209.

51 Parlementaire Geschiedenis Awb III, p. 209.

52 Bijv. 'Tegemoetkomingsregeling oogstschade 2002', Stcrt. 2006, 23

(evenredige verdeling over alle aanvragers) en ABRvS 18 juli 2007, ECLI:NL:RVS:2007:BA9794, AB 2008, 28, m.nt. J.H. van der Grinten en W. den Ouden (loting).

53 Ook wel de postzakproblematiek genoemd.

54 Zie voor een uitgebreide bespreking van de jurisprudentie: M.J. Jacobs en W. den Ouden, 'Eerlijk zullen wij alles delen... Ontwikkelingen in de jurisprudentie over de verdeling van de subsidiepot', JBplus 2011, p. 35-58 en meer specifiek over de rol van adviseurs bij subsidieverstrekking: M.J. Jacobs en W. den Ouden, 'Verdeling van subsidiegelden door concullega's. De rol van adviseurs bij de verdeling van schaarse subsidies in een beauty contest', in: F.J. van Ommeren, W. den Ouden, C.J. Wolswinkel (red.), 'Schaarse publieke rechten', Boom Juridische Uitgevers 2011.

55 Zie recent C.J. Wolswinkel, 'De verdeling van schaarse publieke rechten. Op 
zoek naar algemene regels van verdelingsrecht (diss. VU)', Den Haag: BJu 2013.

56 Vgl. voor het subsidierecht CBb 21 december 2011, ECLI:NL:CBB:2011:BU7267 AB 2012, 63, m.nt. A. Drahmann en J.M.J. van Rijn van Alkemade, ABRvS 24 april 2013, ECLI:NL:RVS:13:BZ8429. AB 2013, 327, m.nt. C.J. Wolswinkel. Zie over de algemene ontwikkeling op dit vlak bijv. A. Drahmann, 'Transparantie en mededinging in het Nederlandse bestuursrecht: van opdrachten, via concessies naar vergunningen?', NALL 2012, DOI 10.5553/NALL/.000007.

57 Strikt genomen zouden hier ook de incidentele subsidies moeten worden vermeld. Wij menen dat het probleem hier minder groot is juist vanwege het incidentele karakter. Zodra een subsidie een structureler karakter krijgt, moet er alsnog een wettelijke grondslag worden gecreëerd en bij die gelegenheid moet de bevoegde wetgever nadenken over de (meest geschikte) verdeelsystematiek.

58 Parlementaire Geschiedenis Awb III, p. 201.

59 Parlementaire Geschiedenis Awb III, p. 201.

6o ABRvS 20 oktober 2010, ECLI:NL:RVS:2010:BO1191, AB 2011, 232, m.nt. W. den Ouden, JB 2011, 3, m.nt. M.J. Jacobs (Coach4Kids).

61 Zie daarover Van den Brink 2012, p. 172 e.v.

62 M.J. Jacobs en W. den Ouden, 'Eerlijk zullen wij alles delen... Ontwikkelingen in de jurisprudentie over de verdeling van de subsidiepot', JBplus 2011, p. 56-57, C.J. Wolswinkel, 'De verdeling van schaarse publieke rechten. Op zoek naar algemene regels van verdelingsrecht (diss. VU)', Den Haag: BJu 2013.

63 Parlementaire Geschiedenis Awb III, p. 172.

64 Parlementaire Geschiedenis Awb III, p. 172.

65 Zie voor de totstandkomingsgeschiedenis van art. 4:36: M.J. Jacobs, 'Subsidieovereenkomsten: Een onderzoek naar de rechtsvormen van subsidies (diss. VU)', Elsevier 1999, p. 126-140 en verder ook Den Ouden, Jacobs \& N. Verheij 2011, hoofdstuk 11.

66 M.J. Jacobs en W. den Ouden, 'Hoedt u voor artikel 4:36 Awb!', NTB 1997, p. 254-266.

67 Hoe vaak er gebruik wordt gemaakt van de bevoegdheid om uitvoeringsovereenkomsten te sluiten is niet bekend. Overigens is ons opgevallen dat er ook wetten/regelingen zijn, die verplichten tot het sluiten van uitvoeringsovereenkomsten. Zie bijv. artikel 2 Regeling aanwijzing categorieën duurzame energieproductie 2013 dat verplicht tot het sluiten van een uitvoeringsovereenkomst indien er meer dan $€ 400$ miljoen aan subsidie wordt verleend, artikel 5.3 Subsidieregeling internationaal excelleren, artikel 61 Besluit stimulering duurzame energieproductie en artikel 7 van de hierna nog te bespreken Experimentenwet BI-Zones. 
68 ABRvS 19 april 2006, ECLI:NL:RVS:2006:AW2275, AB 2006, 296, m.nt. M.J. Jacobs en W. den Ouden.

69 Bijv. ABRvS, 28 juni 2006, ECLI:NL:RVS:2006:AX9453, AB 2006, 326, m.nt. W. den Ouden, CBb 18 januari 2007, ECLI:NL:CBB:2007:AZ7224, AB 2007, 66, m.nt. I. Sewandono, CBb 24 februari 2005, ECLI:NL:CBB:2005:AT1735 AB 2005, 165, m.nt. J.H. van der Veen, JB 2005, 225, m.nt. AJB.

$70 \mathrm{CBb} 18$ november 2011, ECLI:NL:CBB:2011:BU6858, CBb 20 september 2012, ECLI:NL:CBB:2012:BX8582, ABRvS 3 oktober 2012, ECLI:NL:RVS:2012:BX8975, AB 2013, 157, m.nt. J.R. van Angeren.

71 Rb. Assen 29 maart 2012, ECLI:NL:RBASS:2012:BWo841, BB 2012, 289, m.nt. J.P. Kruimel, Rb. Maastricht 27 november 2012, ECLI:NL:RBMAA:2012:BY4635, BB 2013, 6, m.nt. J.P. Kruimel. Ook reparatie van de verordening met terugwerkende kracht kon in de ogen van diverse rechtbanken geen genade vinden. Aangezien belasting alleen kan worden geheven op basis van wet- en regelgeving die is vastgesteld en inwerking getreden op het tijdstip waarop de belastingplicht ontstaat, spreekt dit voor zich (zie bijv. Rb. Den Haag 24 januari 2013, ECLI:NL:RBDHA:2013:BZ1701, BB 2013, 117, m.nt. Kruimel, Rb. Noord-Nederland 25 april 2013, ECLI:NL:RBNNE:2013:CA0943, BB 2013, 297, m.nt. A.W. Schep.

72 Wat in de praktijk overigens soms verre van eenvoudig is: zie bijv. ABRvS 16 oktober 2013, ECLI:NL:RVS:2013:1511.

73 Kamerstukken II 1993/94, 23 700, nr. 3, p. 27.

74 Zie bijv. ABRvS 8 februari 2000, ECLI:NL:RVS:2000:AA5252, AB 2001, 118, m.nt. L.J.A. Damen (woningverbeteringssubsidie Den Haag) en ABRvS 18 juli 2007, ECLI:NL:RVS:2007:BA9812, AB 2007, 349, m.nt. T. Barkhuysen en W. Den Ouden, JB 2007, 169 (Triplewood).

75 Zie bijv. ABRvS 8 mei 2002, ECLI:NL:RVS:2002:AE2396, AB 2003, 137, m.nt. N. Verheij, ABRvS 25 juli 2007, ECLI:NL:RVS:2007:BBo358, AB 2007, 350, m.nt. W. den Ouden en ABRvS 21 mei 2008, ECLI:NL:RVS:2008:BD2138, JB 2008, 155.

76 Zie bijv. CBb 27 november 2001, ECLI:NL:CBB:2001:AD7617, AB 2002, 31, m.nt. J.H. van der Veen, CBb 18 februari 2007, ECLI:NL:CBB:2007:AZ9559 en CBb 7 juni 2011, ECLI:NL:CBB:2011:BQ8474, AB 2011/278, m.nt. W. den Ouden.

77 Zie Kamerstukken met nr. 32838 en Stb. 2012, 527.

78 Zie bijv. al ARRvS 7 oktober 1977, AB 1978, 7 (Beëindiging subsidiëring operagezelschap Forum).

79 Zie bijv. ABRvS 22 maart 2006, ECLI:NL:RVS:2006:AV6288, AB 2006, 378, m.nt. W. den Ouden (Bond van Plattelandsvrouwen).

8o Bijv. ABRvS 20 december 2006, ECLI:NL:RVS:2006:AZ4820, AB 2007, 
234, m.nt. W. den Ouden (Stichting Platform Surinaams Welzijnswerk Rotterdam).

81 W. den Ouden, De overgangssubsidie als smeerolie bij frictiekosten. Nadeelcompensatie bij de beëindiging van langdurige subsidierelaties, van langdurige subsidierelaties' in: T. Barkhuysen, w. den Ouden, M.K.G. Tjepkema (red.), 'Coulant compenseren? Over overheidsaansprakelijkheid en rechtspolitiek', Deventer: Kluwer. 536-555.

82 Aldus reeds ARRvS 21 maart 1985, tB/S III 605 (de Nieuwe Komedie) en daarna keer op keer herhaald met de formulering dat het bestuursorgaan op dit punt een ruime beleidsvrijheid toekomt (bijv. ABRvS 7 juni 2006, ECLI:NL:RVS:2006:AX7048, ABRvS 26 maart 2008, ECLI:NL:RVS:2008:BC7627, ABRvS 10 juni 2009, ECLI:NL:RVS:2009:BI7248, AB 2009, 369, m.nt. M. Nijhuis en W. den Ouden en ABRvS 16 januari 2013, ECLI:NL:RVS:2013:BY8520, AB 2013, 127).

83 ABRvS 26 maart 2008, ECLI:NL:RVS:2008:BC7627 (vgl. ook ABRvS 10 juni 2009, ECLI:NL:RVS:2009:BI7248, AB 2009, 369, m.nt. W. den Ouden).

84 Vgl. ABRvS 26 maart 2008, ECLI:NL:RVS:2008:BC7627.

85 ABRvS 7 juni 2006, ECLI:NL:RVS:2006:AX7048, r.o. 2.15.1.

86 Zie bijv. ABRvS 27 juli 2005, ECLI:NL:RVS:2005:AUo095, AB 2006, 177 en ABRvS 7 juni 2006, ECLI:NL:RVS:2006:AX7048.

87 Bijv. ABRvS 12 september 2001, ECLI:NL:RVS:2001:AN6776, AB 2001, 335, m.nt. N. Verheij (Catalpa) en ABRvS 26 maart 2008, ECLI:NL:RVS:2008:BC7627 (Stichting Spirit).

88 Bijv. ABRvS 7 februari 2007, ECLI:NL:RVS:2007:AZ7971, AB 2007, 235, m.nt. W. den Ouden (Stichting Volksuniversiteit Venray).

89 Zie ABRvS 16 januari 2013, ECLI:NL:RVS:2013:BY8502, AB 2013, 128, m.nt. W. den Ouden en ABRvS 6 februari 2013, ECLI:NL:RVS:2013:BZo700, AB 2013, 313, m.nt. H.F.T. Pennarts.

90 Richtinggevend voor het antwoord op die vraag: HvJEU 5 juni 2012, Case C489/10 (Bonda), AB 2012/315, m.nt. Widdershoven. Uit dit arrest blijkt dat het Hof subsidiesancties in beginsel niet als criminal charge beschouwt.

91 Zie daarover uitgebreid J.E. van den Brink, 'De uitvoering van Europese subsidieregelingen in Nederland. Juridische knelpunten en uitdagingen', Deventer: Kluwer 2013.

92 Zie recentelijk bijv. HvJ EU 5 juni 2012, zaak C -489/10, AB 2012, 315, m.nt. R.J.G.M. Widdershoven.

93 Zie J.E. van den Brink, 'De uitvoering van Europese subsidieregelingen in Nederland. Juridische knelpunten en uitdagingen', Deventer: Kluwer 2013.

94 Kamerstukken II 1003/94, 23 700, p. 28-29. 
95 Daarvoor verwijzen wij naar P.C. Adriaanse en J.R. van Angeren, 'De Awb en staatssteunvragen', in: T. Barkhuysen, W. den Ouden en J.E.M. Polak (red.), 'Bestuursrecht harmoniseren: 15jaar Awb', Den Haag: BJu 2010, pp. 669-686.

96 HvJ EG 13 juni 2002, AB 2002, 248, m.nt. F.H. van der Burg.

97 ABRvS 21 oktober 1996, ECLI:NL:RVS:1996:ZF2335, AB 1996, 496, m.nt. N. Verheij.

98 ABRvS 11 januari 2006, ECLI:NL:RVS:2006:AU9416, AB 2006, 208, m.nt. W. den Ouden en M\&M 2006, p. 93-96, m.nt. J.R. van Angeren.

99 Kamerstukken II 2007/o8, 31 418, nrs. 1-3. Zie verder P.C. Adriaanse en W. den Ouden, 'Effectuering van staatssteunrecht in Nederland. Een

bestuursrechtelijke blik op de uitvoeringspraktijk en het Wetsvoorstel terugvordering staatssteun', NTB 2008, p. 304 e.v.

100 Soms wel tot 30\% van het beschikbare subsidiebudget. Zie hierover de toelichting bij de Aanwijzingen voor subsidieverstrekking (Stcrt. 2009, nr. 20306).

101 Kamerstukken II 2008/o9, 31865 en 31 031, nr. 5, p. 10.

102 Kamerstukken II, 2007/o8, 31 031/29 949, nr. 19, p. 1.

103 Stcrt. 2009, nr. 20306. De Aanwijzingen zijn in werking getreden op 1 januari 2010 en er gold een overgangsperiode tot 1 januari 2012 zodat de betrokken ministeries hun subsidieregelingen konden aanpassen.

104 Hoewel de 'Aanwijzingen voor subsidieverstrekking' gelden voor de opstellers van rijkssubsidieregelingen, hebben zij een verdergaande betekenis gekregen. Zo heeft de VNG in haar modelsubsidieverordening elementen van het uniforme subsidiekader overgenomen.

105 Volgens de Aanwijzingen zijn subsidies beneden $€ 25.000$ klein, subsidies tussen $€$ 25.000 en $€$ 125.000 middelgroot en subsidies boven $€$ 125.000 groot.

106 Zie hierover verder hoofdstuk 3 van Den Ouden, Jacobs \& Verheij 2011..

107 Brief van 12 augustus 2013, Kamerstukken 2012/13, 31 865, nr. 52.

108 Monitoringsrapportage USK, p. 10.

109 Wij schrijven "in beginsel” omdat er bepaalde Europese subsidies zijn waarbij wel met punitieve sancties wordt gewerkt. Het voert te ver om daar nu dieper op in te gaan, zeker omdat het uniforme subsidiekader en de 'Aanwijzingen voor subsidies' niet van toepassing zijn op Europese subsidies.

110 Op p. 11 van de monitoringsrapportage USK staat: "Verder blijkt dat beleidsmedewerkers er eerder voor kiezen om bijvoorbeeld tussentijds beschikkingen aan te passen, dan dat ze sancties opleggen." Het "tussentijds aanpassen van beschikkingen" kan in dit verband moeilijk anders worden opgevat dan als het "wijzigen ten nadele van de ontvanger" (zie afd. 4.2.6 Awb). 
Beschikkingen waarin dergelijke wijzigingen worden vervat, volgen doorgaans als sanctie op verwijtbaar gedrag van de ontvanger, zoals het niet voldoen aan subsidieverplichtingen.

111 Kamerstukken II 2003/O4, 29 200, nr. 40 (Motie Van As), Kamerstukken II 2011/12, 33 034, nr. 8, p. 1.

112 Kamerstukken II 2011/12, 33 034, nr. 8, p. 1.

$\mathbf{1 1 3}$ Op grond van het vijfde lid van Aanwijzing 6A kan de termijn ook langer zijn, maar dan moet de ontwerp-regeling worden voorgehangen bij de Tweede Kamer zodat deze in de gelegenheid is om opmerkingen te maken en daarover met de betrokken bewindspersoon van gedachten te wisselen (zie aanwijzing 36 Ar).

114 Parlementaire Geschiedenis Awb III, p. 203-204.

115 Parlementaire Geschiedenis Awb III, p. 204.

116 Zie ook Parlementaire Geschiedenis Awb III, p. 204.

$\mathbf{1 1 7}$ Onnodig om te zeggen wellicht, maar als de verlengingsregeling onverhoopt te laat gereed mocht zijn, is de subsidieregeling wel vervallen. Bestuursorganen die desondanks subsidie verlenen handelen in strijd met artikel 4:23 Awb. In paragraaf 4 schreven wij dat de bestuursrechter in dergelijke gevallen het subsidiebesluit gewoon toetst. Het is dan wel te hopen voor de subsidieontvanger dat niet een derde-belanghebbende beroep heeft ingesteld, want dan kan het nog wel eens slecht voor hem aflopen.

118 Inmiddels hebben we de eerste subsidieregelingen gezien waarin op basis van Aanwijzing 6A een horizonbepaling is opgenomen. In een aantal gevallen is daarin bepaald dat de regeling vervalt met ingang van een bepaalde datum; zie bijv. art. 10 Regeling subsidie regionale expertisecentra in verband met de pakketmaatregel AWBZ 2009. Als er op de vervaldatum geen lopende subsidieverhoudingen (kunnen) zijn is dit een goed bruikbare bepaling. Kunnen er op die datum wel lopende subsidieverhoudingen zijn, dan verdient aanbeveling daar expliciet rekening mee te houden zodat deze subsidieverhoudingen ordentelijk kunnen worden afgerond (bijv. "Deze regeling vervalt met ingang van $\mathrm{XX}-\mathrm{XX}-20 \mathrm{XX}$, met dien verstande dat zij van toepassing blijft op de subsidies die voor die datum zijn verleend"). Er dient wel rekening mee te worden gehouden dat deze regelingen na de vervaldatum lastiger terug te vinden zijn in databanken (men moet namelijk op het idee komen om ook in de vervallen regelingen te gaan zoeken). Voorbeelden van regelingen waarin op de hiervoor vermelde wijze rekening is gehouden met op de vervaldatum bestaande subsidieverhoudingen zijn: art. 16 Subsidieregeling Fietsersbond 2013 en art. 16 Subsidieregeling gesloten jeugdzorg 2013/2014.

119 Zie K.M. Westra \& W. den Ouden, 'Algemeen bestuursrecht 2001: Subsidies', Den Haag 2001.

120 Deze voordelen gelden niet alleen voor het subsidierecht, maar in zijn algemeenheid voor de gehele Awb. Zie hierover B.J. Schueler, 'De Awb en de bijzondere delen van het bestuursrecht', in: T. Barkhuysen, W. den Ouden en 
J.E.M. Polak (red.), 'Bestuursrecht harmoniseren: 15jaar Awb’, BJu 2010.

121 Bijv. het werkprogramma "Subsidie zonder moeite" dat in opdracht van het ministerie van BZK en de VNG en in samenwerking tussen gemeenten is ontwikkeld. Doel is vermindering van de administratieve en bestuurlijke lasten en verbetering van de dienstverlening. Te bereiken via www.vng.nl.

122 Algemene Rekenkamer, Leren van subsidie-evaluaties, 2011, p. 10 (uit het onderzoek blijkt dat in de periode 2005-2009 81 van de 633 onderzochte subsidieregelingen zijn geëvalueerd).

123 Kamerstukken II, 2007/o8, 31031 en 29 949, nr. 19, p. 6.

124 Voorontwerp Algemene wet bestuursrecht, eerste deel, Den Haag 1987, p. II. 